\title{
Hydrologic and Salinity Characteristics of Currituck Sound and Selected Tributaries in North Carolina and Virginia, 1998-99
}

By William S. Caldwell

\section{U.S. GEOLOGICAL SURVEY}

Water-Resources Investigations Report 01-4097

Prepared in cooperation with the NORTH CAROLINA DIVISION OF WATER RESOURCES and the NORTH CAROLINA DIVISION OF MARINE FISHERIES

Raleigh, North Carolina 2001

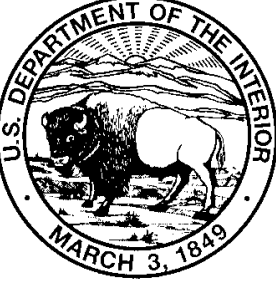




\section{U.S. DEPARTMENT OF THE INTERIOR \\ GALE A. NORTON, Secretary}

U.S. GEOLOGICAL SURVEY

CHARLES G. GROAT, Director

The use of firm, trade, and brand names in this report is for identification purposes only and does not constitute endorsement by the U.S. Geological Survey.

For additional information write to:

District Chief

U.S. Geological Survey

3916 Sunset Ridge Road

Raleigh, NC 27607

dc_nc@usgs.gov
Copies of this report can be purchased from:

U.S. Geological Survey

Branch of Information Services

Box 25286, Federal Center

Denver, CO 80225

1-888-ASK-USGS 
Cover photograph: Data-collection site in Currituck Sound at Poplar Branch, North Carolina, August 31, 1998, following Hurricane Bonnie. Taken by William S. Caldwell, U.S. Geological Survey. 


\section{CONTENTS}

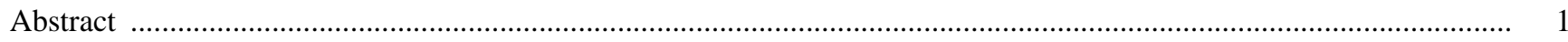

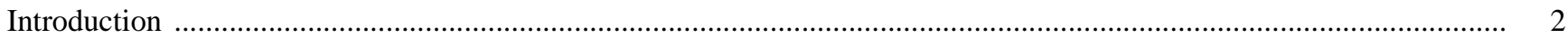

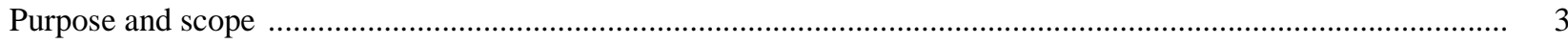

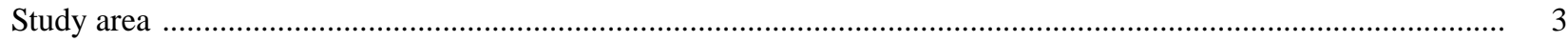

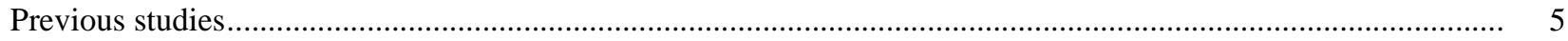

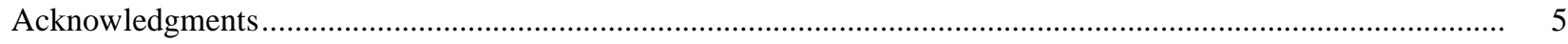

Data collection

Water levels

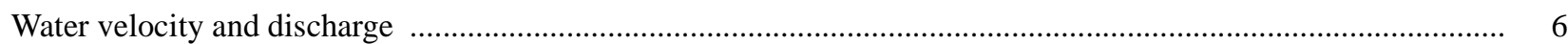

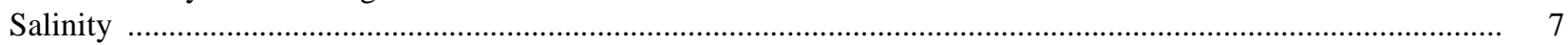

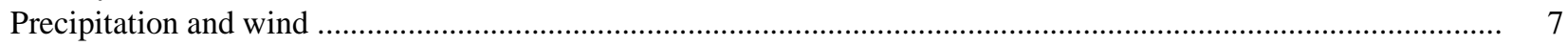

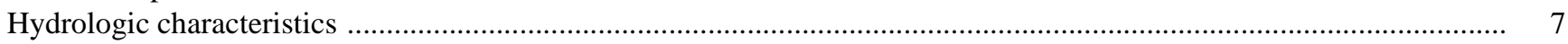

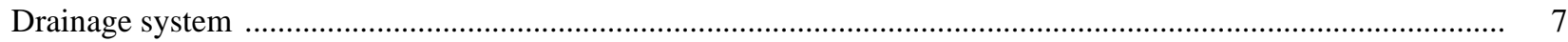

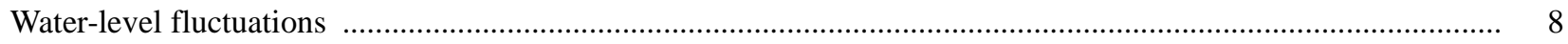

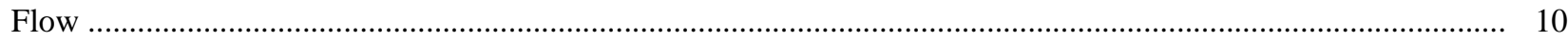

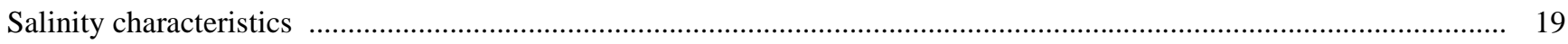

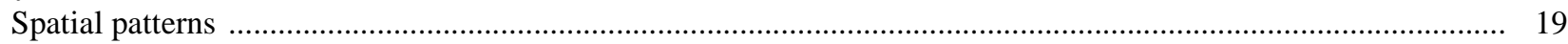

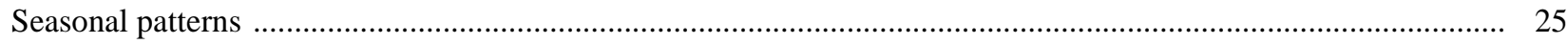

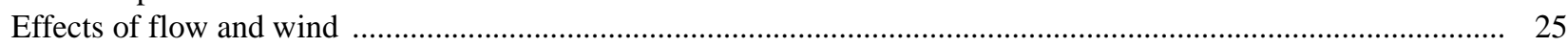

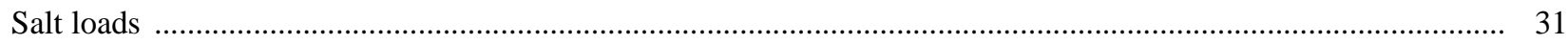

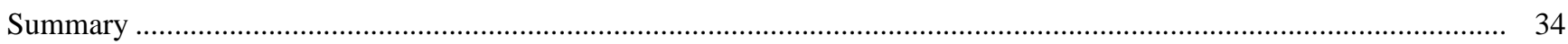

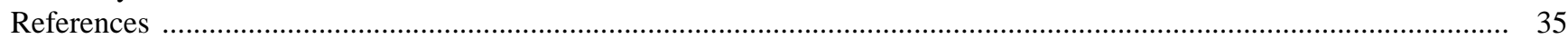

\section{FIGURES}

1. Map showing locations of study sites in the Currituck Sound study area, North Carolina and Virginia,

March 1, 1998, through February 28, 1999.

2-11. Graphs showing:

2. Daily maximum and minimum water leve1s at the Currituck Sound and tributary study sites from March 1, 1998, to February 28, 1999.

3. Cumulative frequency distribution of flows at (A) West Neck Creek (site WN2) and (B) Coinjock (site CU2) from March 1, 1998, to February 28, 1999

. Flow at (A) West Neck Creek (site WN2) and (B) Coinjock (site CU2), May 21-28, 1998

5. (A) Daily net flow volume and (B) cumulative flow volume at West Neck Creek (site WN2) from March 1, 1998, to February 28, 1999

6. (A) Daily net flow volume and (B) cumulative flow volume at Coinjock (site CU2) from March 1, 1998, to February 28, 1999

7. (A) Percentage of time wind blew from indicated direction and (B) frequency of occurrence of measured hourly wind speed at site WS1 from March 1, 1998, to January 3, 1999, and (C) percentage of time wind blew from indicated direction and (D) frequency of occurrence of measured hourly wind speed at site WS1 for the period January 1979 through May $1998 . . .$.

8. Relation of hourly flow to hourly wind direction at West Neck Creek (site WN2) and Coinjock (site CU2) for the periods (A) April 21-29, 1998, and (B) August 17-25, 1998

. Daily maximum salinity at the Currituck Sound and tributary study sites from

March 1, 1998, to February 28, 1999

10. Cumulative frequency distribution of salinity at the Currituck Sound and tributary study sites from March 1, 1998, to February 28, 1999

11. Comparison of daily maximum salinity at sites WN2, AC1, and CU4 from March 1, 1998, to February 28, 1999. 
12-13. Maps showing:

12. Locations of transects and salinity profile data at selected Currituck Sound study sites, June 9, 1998 .

13. Prevailing wind direction resulting in (A) increased salinities and (B) decreased salinities at Currituck Sound and tributary study sites, March 1, 1998, to February 28, 1999

14-19. Graphs showing:

14. Relation of the direction of prevailing winds and daily maximum salinities

at West Neck Creek (site WN2) during selected periods

15. Relation of the direction of prevailing winds and daily maximum salinities at Coinjock (site CU2) during selected periods....

16. Relation of the direction of prevailing winds and daily maximum salinities at Point Harbor (site CU4) during selected periods.

17. Comparison of daily maximum salinity and daily maximum water level at the Currituck Sound and tributary sites for the period March 1, 1998, to February 28, 1999

18. Daily and cumulative daily salt loads, in tons, at West Neck Creek (site WN2) for the period March 1998 through February 1999.

19. Daily and cumulative daily salt loads, in tons, at Coinjock (site CU2) for the period March 1998 through February 1999.

Tables

1. Data-collection sites in the Currituck Sound study area, North Carolina and Virginia, 1998-99

2. Water-level characteristics at the Currituck Sound and tributary study sites based on measurements made from March 1, 1998, to February 28, 1999

3. Summary of flow characteristics at West Neck Creek (site WN2) and Coinjock (site CU2) based on 15-minute interval measurements made from March 1, 1998, to February 28, 1999.

4. Largest precipitation events and associated winds and daily net flows at West Neck Creek (site WN2) and Coinjock (site CU2)

5. Highest daily net flow volumes at West Neck Creek (site WN2) and Coinjock (site CU2) and associated precipitation and winds

6. Salinity characteristics at the Currituck Sound and tributary study sites based on measurements made from March 1, 1998, to February 28, 1999.

7. Selected water-quality values measured along three transects in Currituck Sound, June 9, 1998

8. Summary of events associated with the highest daily maximum salinities at the Currituck Sound and tributary study sites from March 1, 1998, to February 28, 1999.

9. Summary of the highest daily salt loads at West Neck Creek (site WN2) and Coinjock (site CU2), and the relation of precipitation, flow, and wind direction and speed 
CONVERSION FACTORS, VERTICAL DATUM, SPECIFIC CONDUCTANCE, TEMPERATURE, AND DEFINITIONS

\begin{tabular}{rcl}
\hline Multiply & by & To obtain \\
\hline & Length & \\
inch (in.) & 2.54 & centimeter \\
foot (ft) & 0.3048 & meter \\
mile (mi) & 1.609 & kilometer \\
& Area & \\
acre & 0.4047 & hectare \\
acre-foot (acre-ft) & 1,233 & cubic meter \\
square mile $\left(\mathrm{mi}^{2}\right)$ & 2.590 & square kilometer \\
& Volume & \\
cubic foot $\left(\mathrm{ft}^{3}\right)$ & 0.02832 & cubic meter \\
& Flow & \\
cubic foot per second $\left(\mathrm{ft}^{3} / \mathrm{s}\right)$ & 0.02832 & cubic meter per second \\
inch per year $(\mathrm{in} / \mathrm{yr})$ & 25.4 & millimeter per year \\
mile per hour $(\mathrm{mph})$ & 1.609 & kilometer per hour \\
& Mass & \\
ton per day (ton/d) & 0.9072 & megagram per year \\
\hline
\end{tabular}

Sea level: In this report, "sea level" refers to the National Geodetic Vertical Datum of 1929 (NDVD of 1929) - a geodetic datum derived from a general adjustment of the first-order level nets of the United States and Canada, formerly called Sea Level Datum of 1929.

$\underline{\text { Specific conductance }}$ is given in microsiemens per centimeter at 25 degrees Celsius $\left(\mu \mathrm{S} / \mathrm{cm}\right.$ at $\left.25^{\circ} \mathrm{C}\right)$.

Temperature: Water temperature is given in degrees Celsius $\left({ }^{\circ} \mathrm{C}\right)$, which can be converted to degrees Fahrenheit $\left({ }^{\circ} \mathrm{F}\right)$ as follows:

$$
{ }^{\circ} \mathrm{F}=\left(1.8 \mathrm{x}{ }^{\circ} \mathrm{C}\right)+32
$$

\section{Definitions:}

\begin{tabular}{|c|c|}
\hline AIWW & $\begin{array}{l}\text { Atlantic Intracoastal Waterway } \\
\text { acoustic velocity meter }\end{array}$ \\
\hline $\begin{array}{l}\text { AVM } \\
\text { DENR }\end{array}$ & $\begin{array}{l}\text { acoustic velocity meter } \\
\text { North Carolina Department of Environment and Natural Resources (formerly }\end{array}$ \\
\hline & $\begin{array}{l}\text { known as the North Carolina Department of Environment, Health, and Natural } \\
\text { Resources [DEHNR]) }\end{array}$ \\
\hline EC & electrical conductivity \\
\hline hrs & hours \\
\hline ppt & parts per thousand \\
\hline USACE & U.S. Army Corps of Engineers \\
\hline USGS & U.S. Geological Survey \\
\hline VDEQ & Virginia Department of Environmental Quality \\
\hline
\end{tabular}




\title{
Hydrologic and Salinity Characteristics of Currituck Sound and Selected Tributaries in North Carolina and Virginia, 1998-99
}

\author{
By William S. Caldwell
}

\section{ABSTRACT}

Data collected at three sites in Currituck Sound and three tributary sites between March 1, 1998, and February 28, 1999, were used to describe hydrologic and salinity characteristics of Currituck Sound. Water levels and salinity were measured at West Neck Creek at Pungo and at Albemarle and Chesapeake Canal near Princess Anne in Virginia, and at Coinjock, Bell Island, Poplar Branch, and Point Harbor in North Carolina. Flow velocity also was measured at the West Neck Creek and Coinjock sites.

The maximum water-level range during the study period was observed near the lower midpoint of Currituck Sound at Poplar Branch. Generally, water levels at all sites were highest during March and April, and lowest during November and December. Winds from the south typically produced higher water levels in Currituck Sound, whereas winds from the north typically produced lower water levels. Although wind over Currituck Sound is associated with fluctuations in water level within the sound, other mechanisms, such as the effects of wind on Albemarle Sound and on other water bodies south of Currituck Sound, likely affect low-frequency water-level variations in Currituck Sound.

Flow in West Neck Creek ranged from 313 cubic feet per second to the south to -227 cubic feet per second to the north (negative indicates flow to the north). Flow at the Coinjock site ranged from 15,300 cubic feet per second to the south to $-11,700$ cubic feet per second to the north. Flow was to the south 68 percent of the time at the West Neck Creek site and 44 percent of the time at the Coinjock site. Daily flow volumes were calculated as the sum of the instantaneous flow volumes. The West Neck Creek site had a cumulative flow volume to the south of $7.69 \times 10^{8}$ cubic feet for the period March 1, 1998, to February 28, 1999; the Coinjock site had a cumulative flow volume to the north of $-1.33 \times 10^{10}$ cubic feet for the same study period.

Wind direction and speed influence flow at the West Neck Creek and Coinjock sites, whereas precipitation alone has little effect on flow at these sites. Flow at the West Neck Creek site is semidiurnal but is affected by wind direction and speed. Flow to the south (positive flow) was associated with wind speeds averaging more than 15 miles per hour from the northwest; flow to the north (negative flow) was associated with wind speeds averaging more than 15 miles per hour from the south and southwest. Flow at the Coinjock site reacted in a more unpredictable manner and was not affected by winds or tides in the same manner as West Neck Creek, with few tidal characteristics evident in the record.

Throughout the study period, maximum salinity exceeded 3.5 parts per thousand at all sites; however, mean and median salinities were below 3.5 parts per thousand at all sites except the Point Harbor site (3.6 and 4.2 parts per thousand, respectively) at the southern end of the sound. Salinities were less than or equal to 3.5 parts per thousand nearly 100 percent of the time at the Bell 
Island and Poplar Branch sites in Currituck Sound and about 86 percent of the time at the Albemarle and Chesapeake Canal site north of the sound. Salinity at the West Neck Creek and Coinjock sites was less than or equal to 3.5 parts per thousand about 82 percent of the time.

During this study, prevailing winds from the north were associated with flow to the south and tended to increase salinity at the West Neck Creek and the Albemarle and Chesapeake Canal sites. Conversely, these same winds tended to decrease salinity at the other sites. Prevailing winds from the south and southwest were associated with flow to the north and tended to increase salinity at the Poplar Branch and Point Harbor sites in Currituck Sound and at the Coinjock site, but these same winds tended to decrease salinity at the West Neck Creek and the Albemarle and Chesapeake Canal sites. The greatest variations in salinity were observed at the northernmost site, West Neck Creek, and the southernmost site, Point Harbor. The least variation in salinity was observed at the upper midpoint of the sound at the Bell Island site.

Daily salt loads were computed for 364 days at the West Neck Creek site and 348 days at the Coinjock site from March 1, 1998, to February 28, 1999. The cumulative salt load at West Neck Creek was 28,170 tons to the south, and the cumulative salt load at the Coinjock site was $-872,750$ tons to the north.

The cumulative salt load passing the West Neck Creek site during the study period would be 0.01 part per thousand if uniformly distributed throughout the sound (approximately 489,600 acre-feet in North Carolina). If the cumulative salt load passing the Coinjock site were uniformly distributed throughout the sound, the salinity in the sound would be 0.32 part per thousand. The net transport at the West Neck Creek and Coinjock sites indicates inflow of salt into the sound. A constant inflow of freshwater from tributaries and ground-water sources also occurs; however, the net flow volumes from these freshwater sources are not documented, and the significance of these freshwater inflows toward diluting the net import of salt into the sound is beyond the scope of this study.

\section{INTRODUCTION}

During the 1970's, Currituck Sound was well known for its freshwater fisheries (Venters, 1995). By the late 1980's, however, comparisons of fishpopulation surveys revealed a notable change from freshwater species to estuarine species in the sound-a change that was attributed to an increase in salinity in Currituck Sound (Kornegay, 1989).

Previous studies by Kornegay (1989) and the Hampton Roads Planning District Commission (1992) documented periodic fluctuations of salinity and the effects of salinity on freshwater fisheries in Currituck Sound. Increased salinity in the sound has been attributed to droughts and the pumping of seawater into Back Bay, which occurred between 1965 and 1987 (Y. Barber, Currituck County volunteer, written commun., 1993). Salt also moves into Currituck Sound from the north by way of West Neck Creek through North Landing River or the Albemarle and Chesapeake Canal, or from the south by way of Albemarle Sound through the Atlantic Intracoastal Waterway (AIWW) or through the mouth of the sound (Bales and Skrobialowski, 1994). Thus, the causes of changes in salinity in Currituck Sound are complex and seem to be the result of both natural and human-induced mechanisms, prompting the need for further investigation.

The total fluxes of water and salt into and out of Currituck Sound remain undocumented. Moreover, the conditions under which these fluxes occur are not well understood. Management plans for the sound and surrounding watershed are being considered; however, development of effective management plans is dependent on good characterization of transport processes affecting the sound and its response to influxes of salt.

In 1997, the U.S. Geological Survey (USGS), in cooperation with the North Carolina Divisions of Water Resources and Marine Fisheries, began a 23-month investigation of salinity and flow into and within Currituck Sound. The objectives of the study were to (1) quantify selected major fluxes of water and salt into and out of Currituck Sound, (2) document salinity variations at selected sites within the sound, and (3) characterize conditions under which major fluxes occur. This investigation complements the findings of a USGS study conducted during 1989-92 (Bales and Skrobialowski, 1994). Interstate water issues and coastal hydrology are a key part of the USGS mission (U.S. Geological Survey, 1999). 


\section{Purpose and Scope}

The purpose of this report is to summarize selected hydrologic and salinity characteristics of Currituck Sound and three of its tributaries, document water and salt fluxes in two tributaries to the sound, and describe variations in salinity within the sound. Data were collected at three locations in Currituck Sound and at three tributary locations to the sound from March 1, 1998, to February 28, 1999. These data include water level, velocity, flow, salinity, and temperature. Selected climatological data were obtained from the National Climatic Data Center (National Oceanic and Atmospheric Administration, written commun., 1999).

\section{Study Area}

Currituck Sound is in northeastern North Carolina in the Coastal Plain Physiographic Province (fig. 1). The North Carolina portion of the sound has a surface area of about 97,900 acres, or about 153 square miles $\left(\mathrm{mi}^{2}\right)$. Currituck Sound is a brackish-water estuary that extends 40 miles (mi) from the VirginiaNorth Carolina State line to its confluence with Albemarle Sound (Eagleson, 1994). The average depth of the sound is about 5 feet $(\mathrm{ft})$. The drainage area of Currituck Sound, including tributaries from both North Carolina and Virginia and Back Bay, is estimated to be $733 \mathrm{mi}^{2}$ (Rideout, 1990), of which almost one-third is open water. The cities of Virginia Beach and

Chesapeake compose most of the land area in Virginia that drains to Currituck Sound; in North Carolina, the land in northwest Currituck County drains to the sound. The exact delineation of the Currituck Sound contributing drainage area is not well defined because of (1) low topographic relief, which ranges from 0 to $30 \mathrm{ft}$ in the basin (Malcolm Pirnie Engineers, Inc., 1980); (2) several canals that connect Currituck Sound to Chesapeake Bay; and (3) bidirectional flow that moves to the north and south.

The climate of the study area is humid subtropical (Trewartha and Horn, 1980). The annual average precipitation is about 45 inches (in.), and monthly totals typically are greatest during the summer. Flood-producing rainfall and high winds generally are associated with hurricanes or tropical storms and(or) convective thunderstorms during the summer or fall. In addition, northeasters can generate strong winds, heavy rainfalls, and high water levels or flooding during the fall and winter.

Three major tributaries supply most of the freshwater to Currituck Sound-North Landing River, Northwest River, and Tull Creek (fig. 1). The drainage area of North Landing River at the Virginia-North Carolina State line is about $117 \mathrm{mi}^{2}$; in 1990 , 44 percent of the drainage area was used for agriculture, 35 percent was undeveloped, 17 percent was developed, and 4 percent was water (Hampton Roads Planning District Commission, 1992). North Landing River is channelized over its entire length as a part of the AIWW and joins the Albemarle and Chesapeake Canal about 12 river mi north of the State line and 3.2 river mi north of the confluence with West Neck Creek. Great Bridge Lock (fig. 1) at the western end of the Albemarle and Chesapeake Canal and about 21 river mi from the State line prevents continuous inflow of water with high salinity from Elizabeth River into the canal and, thus, into Currituck Sound.

From Great Bridge Lock, the AIWW extends east through the Albemarle and Chesapeake Canal and south through North Landing River and into Currituck Sound. About 14 river mi south of the Virginia-North Carolina State line, the AIWW is routed through a land cut near Coinjock to the confluence of North River where the AIWW continues south through the North River, parallel to Currituck Sound, to the confluence with Albemarle Sound (fig. 1).

Before the 1960's, a natural hydraulic connection existed between Lynnhaven Bay in Virginia and Currituck Sound in North Carolina through London Bridge Creek to West Neck Creek (fig. 1; U.S. Army Corps of Engineers, 1996). In the early 1960's, a drainage canal, used primarily for flood control for rural agricultural land, was constructed by the U.S. Soil Conservation Service, currently known as the Natural Resources Conservation Service. This drainage canal bypasses part of London Bridge Creek and is known as Canal No. 2. Over time, flood flows carried by Canal No. 2 increased, and the capacity of the canal often was exceeded because of intensive residential and commercial land development and altered runoff patterns. The West Neck Creek watershed is heavily developed and drains about $37 \mathrm{mi}^{2}$ (U.S. Army Corps of Engineers, 1980). Consequently, a segment of Canal No. 2 was enlarged in 1989 based on recommendations by the U.S. Army Corps of Engineers (USACE). This modification is referred to as the Canal No. 2 Project in this report. 


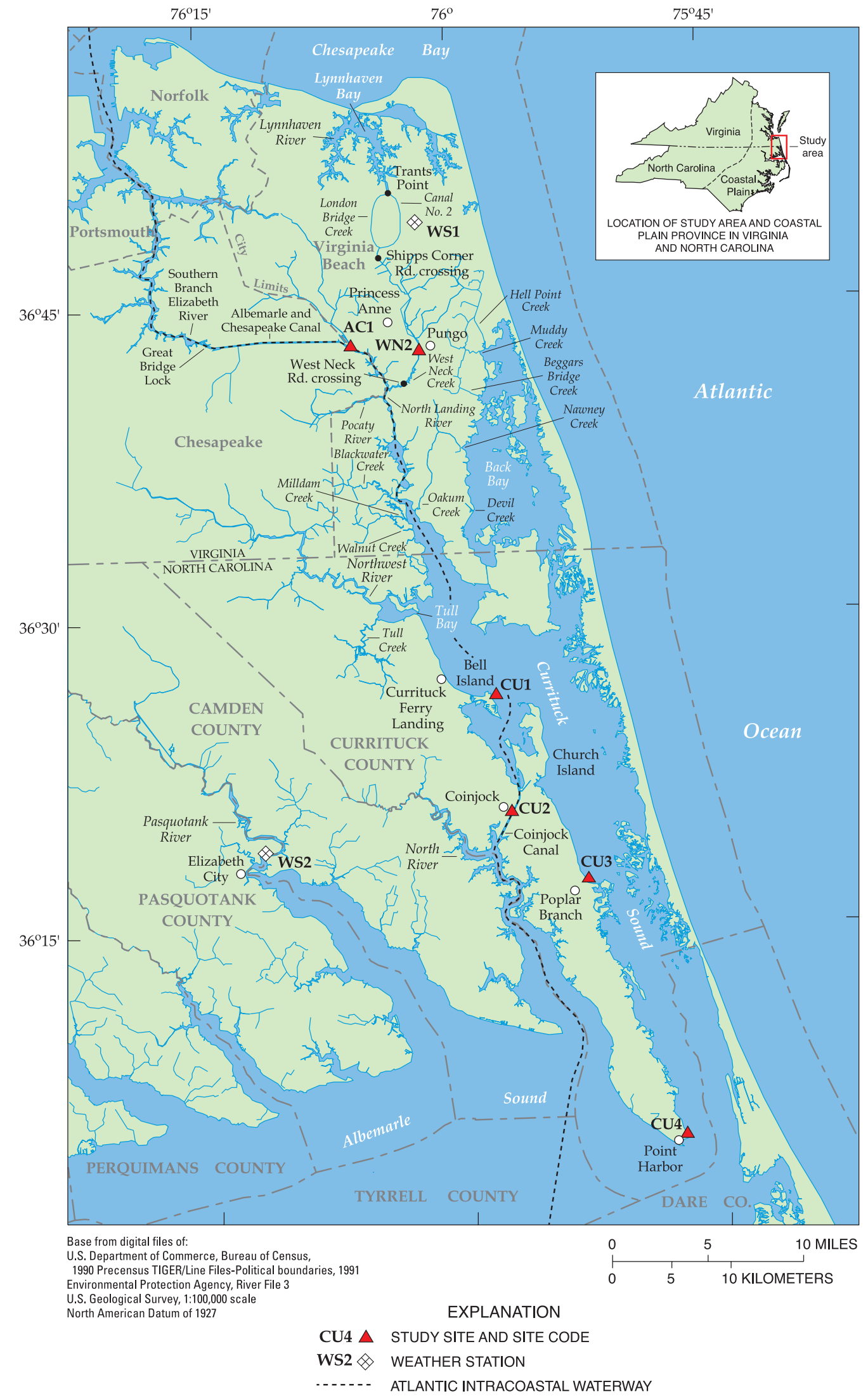

Figure 1. Locations of study sites in the Currituck Sound study area, North Carolina and Virginia, March 1, 1998, through February 28, 1999. 


\section{Previous Studies}

Overton and McAllister (1993) applied a salttransport model to London Bridge Creek, the Canal No. 2 system, and North Landing River. They concluded that salinity entering Canal No. 2 from the north potentially can be transported southward to the mouth of North Landing River under extreme tidal conditions (6.6-ft wind tide) that persist for 5 days or more. Under normal tidal conditions (1.7-ft range), simulation results indicated that salt was not transported southward from Lynnhaven River to the mouth of North Landing River. The model was calibrated by using data collected during the Bales and Skrobialowski (1994) study.

From August 1991 to May 1994, the USACE measured salinity at monthly intervals at selected sites, including Lynnhaven Bay at Trants Point (located near the northern confluence of London Bridge Creek and Canal No. 2; fig. 1) and at the West Neck Creek and Shipps Corner Road crossing (located near the southern confluence of London Bridge Creek and Canal No. 2; fig. 1). These data were compared with data collected by the Virginia Department of Environmental Quality (VDEQ) at the West Neck Creek and West Neck Road crossing before (January 1983-May 1989) and after (June 1989-September 1994) the Canal No. 2 Project. The West Neck Creek and West Neck Road crossing site is located about 1.5 mi east of the confluence of West Neck Creek and North Landing River (fig. 1).

In February 1996, the North Carolina Department of Environment, Health, and Natural resources (currently known as the North Carolina Department of Environment and Natural Resources [DENR]) requested the USACE, Norfolk District, to perform a Section 1135 (Water Resources Development Act of 1986, P.L. 99-662, as amended) study of the Canal No. 2 Project (U.S. Army Corps of Engineers, 1996) to determine if the Canal No. 2 Project had resulted in increased salinity in the northern part of Currituck Sound. The USACE (1996) concluded that the causes of increased salinity in Currituck Sound are complex and could be produced by a variety of mechanisms. The USACE (1996) also concluded that the Canal No. 2 Project had not increased salinity in this area beyond levels that would have occurred prior to the Canal No. 2 Project. The occasional elevated readings in Canal No. 2 were consistent with expected variations as a result of tidal fluctuations; however, salinity readings made at monthly intervals during the 1991-94 study are insufficient to reach conclusions about changes in the Currituck Sound regime. These studies did not conclude how far south the occasional elevated salinity, such as that observed in the southern portion of West Neck Creek, extended into Currituck Sound.

The USGS conducted an investigation to determine flow rates and predominant flow direction in West Neck Creek during 1989-92, and to characterize the salinity in West Neck Creek and North Landing River near the Virginia-North Carolina State line during 1991-92 (Bales and Skrobialowski, 1994). The highest salinity observed was at West Neck Creek during periods of sustained north to northeasterly winds. Simultaneous measurements of flow and salinity were used to compute transport of salt in West Neck Creek. For 294 days, during which simultaneous flow and salinity data were available at West Neck Creek, the net salt transport was 34,510 tons to the south or 0.01 part per thousand (ppt) if uniformly distributed throughout the sound. Southward salt transport ranged from 0.3 to 4,500 tons per day (tons/d), and northward transport ranged from 0.2 to 302 tons/d (Bales and Skrobialowski, 1994).

From January 1989 through June 1998, staff from the North Carolina Wildlife Resources Commission made monthly salinity measurements at four locations in Currituck Sound-Currituck Ferry Landing, Church Island, Poplar Branch, and at the southern end of the sound near Point Harbor (Thomas, 1996). During November 1994 to June 1998, measurements also were made at a fifth site, AIWW at Coinjock (Thomas, 1998). Considering all measurements, salinity ranged from 0.0 to $9.0 \mathrm{ppt}$. The lowest salinity was at Currituck Ferry Landing, and the highest was at the southern end of the sound. Monthly salinity at all sites exceeded $3.5 \mathrm{ppt}$ less than 5 percent of the time. The approximate upper threshold at which largemouth bass can successfully reproduce is $3.5 \mathrm{ppt}$ (Tebo and McCoy, 1964), and is an indicator of the status of the fishery resource.

\section{Acknowledgments}

The USGS thanks the private property owners for their graciousness in allowing access and use of their property for data-collection activities. Specifically, appreciation is extended to Ms. Sarah Roney, Mr. Robert Boyd, and Ms. DeLoise Stonecypher. Also, appreciation is extended to the 
North Carolina Wildlife Resources Commission, the Norfolk District of the U.S. Army Corps of Engineers, and the City of Virginia Beach for their cooperation. A special thank you to Mr. Jerad Bales and Ms. Jeanne Robbins of the USGS, both of whom contributed significantly to this report.

\section{DATA COLLECTION}

Data for this investigation were collected at six locations (fig. 1; table 1) -West Neck Creek at Pungo (WN2); the Albemarle and Chesapeake Canal near Princess Anne (AC1); the AIWW at Coinjock (CU2); and in Currituck Sound at Bell Island (CU1), Poplar Branch (CU3), and Point Harbor (CU4). Salinity, water level, and temperature data were recorded at sites AC1, CU1, CU2, and CU3 from July 1997 through June 1999; at site CU4 from July 1997 through March 1999; and at site WN2 from December 1997 through June 1999. Flow data were collected at sites WN2 and CU2 from February 1998 through June 1999. Data collected from March 1, 1998, to February 28, 1999, were used for the interpretations presented in this report. All data were published in the USGS annual water-resources data report for North Carolina (Ragland and others, 2000).

The northernmost data-collection site was West Neck Creek at Pungo, Va. (site WN2), located about $3 \mathrm{mi}$ south of a site that was used in the 1989-92 study (Bales and Skrobialowski, 1994) and about $7 \mathrm{mi}$ south of the southern confluence of West Neck Creek with London Bridge Creek. The northernmost site in the
1989-92 study could not be used for this study because of bridge construction that was underway during 1997.

\section{Water Levels}

Water levels were measured by using a float mounted in a stilling well. Data were recorded by electronic data loggers to the nearest $0.01 \mathrm{ft}$ at 15-minute intervals. Gage datums were referenced to sea level by leveling to the nearest benchmark. All reported water levels are referenced to sea level.

\section{Water Velocity and Discharge}

Water velocity was measured at sites WN2 and CU2 at 15-minute intervals by using acoustic velocity meters (AVM), sometimes referred to as ultrasonic velocity meters. The AVM determines the magnitude and longitudinal direction of the laterally averaged flow velocity at a specific elevation in the channel (line velocity) by measuring the travel time of an acoustic pulse through the water body. Velocity measurements made by the acoustic method are recognized as reliable and accurate (International Organization for Standardization, 1985). Details on the theory and operation of the AVM system were documented by Laenen (1985). A relation was developed between the cross-sectional mean velocity and AVM-measured line velocity by making standard discharge measurements for a range of flow conditions. A relation also was developed between stage and cross-sectional area. Instantaneous discharge was then computed from

Table 1. Data-collection sites in the Currituck Sound study area, North Carolina and Virginia, 1998-99

[na, not applicable. Latitude and longitude coordinates are referenced to the North American Datum of 1927]

\begin{tabular}{|c|c|c|c|c|c|}
\hline $\begin{array}{l}\text { Site } \\
\text { (fig. 1) }\end{array}$ & $\begin{array}{c}\text { USGS } \\
\text { station } \\
\text { number }\end{array}$ & Site name & Latitude & $\begin{array}{l}\text { Longi- } \\
\text { tude }\end{array}$ & $\begin{array}{c}\text { Salinity } \\
\text { probe } \\
\text { location } \\
\text { (feet } \\
\text { above } \\
\text { channel } \\
\text { bottom) }\end{array}$ \\
\hline WN2 & 02043200 & West Neck Creek at Indian River Road at Pungo, Va. & $36^{\circ} 43^{\prime} 16^{\prime \prime}$ & $76^{\circ} 02^{\prime} 03^{\prime \prime}$ & 3 \\
\hline $\mathrm{AC} 1$ & 02043120 & Albemarle and Chesapeake Canal near Princess Anne, Va. & $36^{\circ} 43^{\prime} 04^{\prime \prime}$ & $76^{\circ} 06^{\prime} 02^{\prime \prime}$ & 4 \\
\hline CU1 & 0204342510 & Currituck Sound at Bell Island, N.C. & $36^{\circ} 25^{\prime} 43^{\prime \prime}$ & $75^{\circ} 58^{\prime} 02^{\prime \prime}$ & 1 \\
\hline CU2 & 0204343500 & Atlantic Intracoastal Waterway at Coinjock, N.C. & $36^{\circ} 20^{\prime} 34^{\prime \prime}$ & $75^{\circ} 57^{\prime} 15^{\prime \prime}$ & 3 \\
\hline CU3 & 0204345010 & Currituck Sound at Poplar Branch, N.C. & $36^{\circ} 17^{\prime} 14^{\prime \prime}$ & $75^{\circ} 53^{\prime} 02^{\prime \prime}$ & 1.5 \\
\hline CU4 & 0204347490 & Currituck Sound near Point Harbor, N.C. & $36^{\circ} 04^{\prime} 52^{\prime \prime}$ & $75^{\circ} 47 ' 28^{\prime \prime}$ & 1 \\
\hline WS1 & na & Oceana Naval Air Station weather station, Va. & $36^{\circ} 49^{\prime}$ & $76^{\circ} 02^{\prime}$ & na \\
\hline WS2 & na & Elizabeth City weather station, N.C. & $36^{\circ} 19^{\prime}$ & $76^{\circ} 12^{\prime}$ & na \\
\hline
\end{tabular}


measurements of line velocity and stage, and application of the line velocity cross-sectional mean velocity and stage area relations.

\section{Salinity}

Specific conductance and water temperature were measured at 15-minute intervals at all sites by using a conductivity/temperature probe (Campbell Scientific, Inc., 1996). Specific conductance and temperature data were collected at approximately midwater depth at each site (table 1). The temperature sensor range is 0 to 50 degrees Celsius $\left({ }^{\circ} \mathrm{C}\right)$ with an accuracy error of $\pm 0.4^{\circ} \mathrm{C}$. The electrical conductivity (EC) sensor range is approximately 5 to 7,500 microsiemens per centimeter at $25^{\circ} \mathrm{C}(\mu \mathrm{S} / \mathrm{cm}$ at $25^{\circ} \mathrm{C}$ ) with an accuracy of \pm 5 percent of the reading range of 440 to $7,000 \mu \mathrm{S} / \mathrm{cm}$. Specific conductance was converted to salinity by using the algorithm given by Miller and others (1988).

Measured specific conductance values exceeded the manufacturer-specified EC sensor range for extended periods of time at sites WN2 and CU4. During each visit to these two sites, the EC readings were checked against four specific conductance standards that ranged from 10,000 to $49,400 \mu \mathrm{S} / \mathrm{cm}$. Adjustments of less than 5 percent typically were required to correct the $\mathrm{EC}$ sensor data that were outside the specified range.

The sites were visited at approximately monthly intervals, at which time data were retrieved, and each sensor was cleaned and checked against appropriate specific conductance standards. A vertical profile of specific conductance and water temperature was measured during each visit to ensure that the measurements at the sensor were representative of conditions over the full depth of flow. Methods similar to those reported by Garrett and Bales (1991) and Robinson and others (1996) were used for servicing the sensors and processing the data.

\section{Precipitation and Wind}

Precipitation and wind data used in this study were provided by the National Climatic Data Center in Asheville, N.C. Only data through January 3, 1999, were available at the time this report was prepared. Precipitation and wind data were measured at the weather station (WS1) at Oceana Naval Air Station in
Virginia Beach, Va., located about 8 mi north of site WN2 (fig. 1). Precipitation accumulations were recorded each day at 0700 hours (hrs) for the previous $24 \mathrm{hrs}$. Wind speed and direction were recorded hourly. Daily precipitation also was measured at the climatological weather station (WS2) in Elizabeth City, N.C., located about $15 \mathrm{mi}$ west of site CU2 (fig. 1).

\section{HYDROLOGIC CHARACTERISTICS}

Currituck Sound is a coastal system characterized by the mixing of freshwater and saltwater. The sound has two hydraulic connections with Chesapeake Bay in Virginia-Canal No. 2 and London Bridge Creek by way of West Neck Creek, and the AIWW by way of the Albemarle and Chesapeake Canal (fig. 1). Currituck Sound also has two hydraulic connections to Albemarle Sound in North Carolina-North River by way of Coinjock Canal and the confluence of Currituck Sound with Albemarle Sound (fig. 1). Thus, flows at these hydraulic connections can move to the south or north depending on prevailing conditions, such as winds and tides.

Wind speed and direction and tides tend to change seasonally and are event driven. Events of low magnitude (astronomical tides) tend to cause flows to move back and forth with little net transport along the northern and southern boundaries of the sound. Events of greater magnitude (strong winds and wind-induced tides) tend to override astronomical tides and push flows farther into the middle of the sound (site CU1) and are associated with increased net transport in and out of the northern and southern boundaries of the sound. Regardless of the magnitude of the prevailing conditions, the least amount of variation in water level and flow over time is near the central portion of the sound.

\section{Drainage System}

The Currituck Sound Basin lies completely within hydrologic unit 03010205 , a $3,750-\mathrm{mi}^{2}$ unit that includes the coastal drainage and associated waters of the Back Bay drainage system to the north and parts of Dare County to the south (Seaber and others, 1987). Currituck Sound has a complex drainage system. The drainage basin, composed of tributaries from North Carolina and Virginia, including Back Bay, is estimated to be $733 \mathrm{mi}^{2}$. An accurate drainage area is difficult to 
delineate because of ambiguous relief, drainage canals that cross topographic divides, and tributaries where water can move toward or away from Currituck Sound.

The tributary having the largest drainage area in the Currituck Sound Basin is North Landing River. The Virginia portion of the North Landing River Basin has a drainage area of about $117 \mathrm{mi}^{2}$ (Hampton Roads Planning District Commission, 1992). Tributaries to North Landing River in Virginia include Pocaty River, Blackwater Creek, Milldam Creek, Oakum Creek, Walnut Creek, and West Neck Creek (fig. 1).

Back Bay is a 25,600-acre $\left(40-\mathrm{mi}^{2}\right)$ estuary located east of the North Landing River Basin (Eagleson, 1994; fig. 1). Back Bay tributaries include Beggars Bridge Creek, Hell Point Creek, Muddy Creek, and Nawney Creek, most of which drain the city of Virginia Beach. Major tributaries to Currituck Sound in North Carolina include Northwest River and Tull Creek (fig. 1).

An estimated 56 percent of the Currituck Sound Basin is in North Carolina; the remaining 44 percent of the basin is in Virginia. Approximately 30 percent of the entire basin is open water.

Average annual rainfall on the sound is approximately 45 in. In general, annual surface runoff volume in northeastern North Carolina is about onethird the amount of rainfall, and annual ground-water runoff is about two-thirds the amount of rainfall (Wilder and others, 1978; Krug and others, 1990). If the average depth of open water in the basin is $5 \mathrm{ft}$, then the total volume of open water in the entire basin is about $3.07 \times 10^{10}$ cubic feet $\left(\mathrm{ft}^{3}\right)$. The sum of the average annual rainfall volume and the average annual runoff volume is about $4.1 \times 10^{10} \mathrm{ft}^{3}$. Hence, the average hydraulic residence time of water in Currituck Sound and adjacent open waters is about three-fourths of a year.

\section{Water-Level Fluctuations}

Water levels fluctuated between -1.79 and $2.66 \mathrm{ft}$ above sea level at site $\mathrm{WN} 2$, a range of $4.45 \mathrm{ft}$ (table 2; fig. 2). The same general range was observed by Bales and Skrobialowski (1994) approximately 3 mi north of site WN2, at West Neck Creek at State Road 149 during 294 days of record from September 1990 through March 1992. Common measurements in table 2 and subsequent tables refer to the set of data recorded simultaneously at all sites during the period March 1, 1998, through February 28, 1999. The highest water levels consistently were observed near the lower midpoint of the sound at site CU3. There was no apparent hydraulic explanation for this phenomenon. Further investigation, including a flow model of the sound, might provide insight into these observations. The maximum water-level range was observed at site CU3; the lowest water-level ranges were near the upper midpoint of the sound at site $\mathrm{CU} 1$ and at site $\mathrm{CU} 2$ (table 2).

Water levels at all sites generally were higher during March and April and lower during November and December throughout the study period. This observation is different from previous observations at two sites on West Neck Creek (Bales and Skrobialowski, 1994). Minimum water levels during 1991-92 generally occurred in winter and spring months, and maximum water levels generally occurred

Table 2. Water-level characteristics at the Currituck Sound and tributary study sites based on measurements made from March 1, 1998, to February 28, 1999

\begin{tabular}{|c|c|c|c|c|c|c|c|c|c|c|}
\hline \multirow[b]{2}{*}{$\begin{array}{l}\text { Site } \\
\text { (fig. 1) }\end{array}$} & \multicolumn{5}{|c|}{$\begin{array}{c}\text { All measurements } \\
\text { (feet above sea level) }\end{array}$} & \multicolumn{5}{|c|}{$\begin{array}{c}\text { Common measurements } \\
\text { (feet above sea level) }\end{array}$} \\
\hline & Mean & Median & $\begin{array}{l}\text { Maximum } \\
\text { observed }\end{array}$ & $\begin{array}{l}\text { Minimum } \\
\text { observed }\end{array}$ & $\begin{array}{c}\text { Number } \\
\text { of } \\
\text { measure- } \\
\text { ments } \\
\text { analyzed }\end{array}$ & Mean & Median & $\begin{array}{l}\text { Maximum } \\
\text { observed }\end{array}$ & $\begin{array}{l}\text { Minimum } \\
\text { observed }\end{array}$ & $\begin{array}{c}\text { Number } \\
\text { of } \\
\text { measure- } \\
\text { ments } \\
\text { analyzed }\end{array}$ \\
\hline WN2 & 0.80 & 0.88 & 2.66 & -1.79 & 35,040 & 0.71 & 0.76 & 2.66 & -1.79 & 25,683 \\
\hline $\mathrm{AC} 1$ & .90 & .98 & 2.73 & -1.90 & 35,040 & .82 & .87 & 2.73 & -1.90 & 25,683 \\
\hline CU1 & 1.07 & 1.12 & 3.00 & -.75 & 34,937 & .98 & 1.00 & 3.00 & -.75 & 25,683 \\
\hline CU2 & .97 & 1.00 & 2.91 & -.79 & 35,040 & .90 & .90 & 2.91 & -.79 & 25,683 \\
\hline CU3 & 1.34 & 1.33 & 4.82 & -.20 & 25,786 & 1.35 & 1.33 & 4.82 & -.20 & 25,683 \\
\hline CU4 & .98 & .98 & 3.86 & -.48 & 33,193 & .92 & .90 & 3.86 & -.48 & 25,683 \\
\hline
\end{tabular}

${ }^{a}$ Data recorded simultaneously at all sites. 


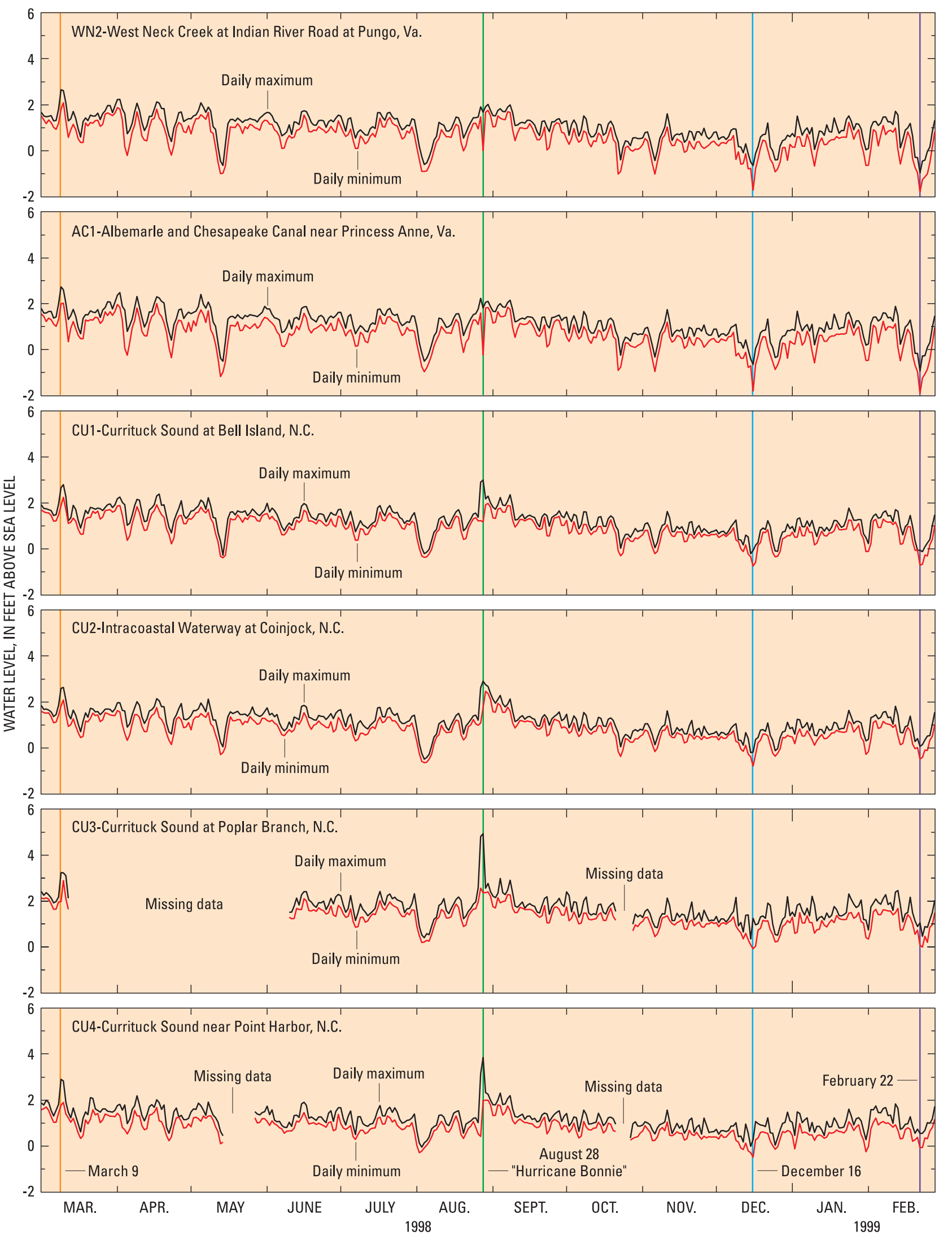

Figure 2. Daily maximum and minimum water levels at the Currituck Sound and tributary study sites from March 1, 1998, to February 28, 1999. 
in summer months. The difference between the 1991-92 and 1998-99 data suggests that water levels in the study area are influenced by mechanisms, such as wind and tides, that vary from year to year as well as daily and seasonally.

During this investigation, maximum water levels observed at sites WN2 and AC1 occurred on March 9, 1998, and minimum water levels occurred at these sites on February 22, 1999 (fig. 2). Maximum water levels at sites CU1, CU2, CU3, and CU4 occurred on August 28, 1998, and minimum water levels at these four sites occurred on December 16, 1998 (fig. 2). Winds, averaging between 8 and 12 miles per hour (mph) out of the south and southwest (August 21-25, 1998) several days prior to the passage of Hurricane Bonnie, generated the high water levels in Currituck Sound on August 28, 1998; however, Hurricane Bonnie did not produce high water levels at sites WN2 and $\mathrm{AC} 1$, probably because these waters are somewhat shielded from winds by surrounding land (fig. 1) and because of minimal effects of Hurricane Bonnie on Chesapeake Bay. High winds from the south produced the highest water levels at sites WN2 and AC1 on March 9, 1998 (fig. 2), when the mean wind speed was $17 \mathrm{mph}$.

No statistical correlation was identified between water levels and precipitation. Generally, the common factor associated with high water levels at all study sites during the study period was prevailing southerly winds (winds from the south) that averaged $12 \mathrm{mph}$ or greater, excluding atypical conditions, such as those generated by a hurricane. Lower water levels generally were associated with prevailing northerly winds (winds from the north).

The times of occurrence of daily maximum and minimum water levels observed at each site were compared for selected days. When winds were from the south, maximum water levels occurred first at sites WN2 and AC1. Within 4 hrs, the maximum water level occurred at site CU4; within $8 \mathrm{hrs}$, maximum water levels were observed at the remaining sites. This pattern changed slightly, however, when wind was predominantly from the southwest. When wind was from the southwest, maximum water levels occurred first at sites $\mathrm{AC} 1$ and $\mathrm{CU} 2$ nearly simultaneously. Within 2 to $6 \mathrm{hrs}$, maximum water levels occurred at the remaining four sites.

Low water levels typically occurred when winds were predominantly from the north with sustained speeds greater than $10 \mathrm{mph}$. When winds were from the northwest, daily minimum water levels typically occurred first at sites WN2, AC1, CU2, and CU4 nearly simultaneously. Minimum water levels then occurred at sites CU1 and CU3 between 5 and $7 \mathrm{hrs}$ later. When wind was from the northeast, minimum water levels typically occurred first at site CU4 followed by minimum water levels at sites WN2, AC1, and CU3 nearly a day later. Minimum water levels occurred at sites CU1 and CU2 as much as 2 days after the minimum water level was observed at site CU4.

Although wind direction and speed over Currituck Sound is associated with changes in water level within the sound, other mechanisms may be important. The effects of wind on Albemarle and other water bodies south of Currituck Sound likely affect low-frequency water-level variations in Currituck Sound. Also, the movement of water in the sound may be a result of a recovery process following a previous event. For example, several days of northerly winds may produce a water-level gradient within the sound. When these winds cease or become calm or moderate (2-5 mph), the sound may recover in a day or two whether or not winds are from the south. This reversal or recovery process may produce brief high water, and southerly winds may sustain this high water even if the winds were not strong enough to initiate the higher water levels.

\section{Flow}

Flow at site WN2 was to the south 68 percent of the time (fig. 3) and ranged from 313 cubic feet per second $\left(\mathrm{ft}^{3} / \mathrm{s}\right)$ to the south to $-227 \mathrm{ft}^{3} / \mathrm{s}$ to the north (table 3). (For this report, positive flows are to the south and negative flows are to the north.) Flow at site CU2 was to the south 44 percent of the time (fig. 3 ) and ranged from $15,300 \mathrm{ft}^{3} / \mathrm{s}$ to the south to $-11,700 \mathrm{ft}^{3} / \mathrm{s}$ to the north (table 3 ). On average, the net daily flow volume to the south at site CU2 was 55 times greater than at site WN2. Likewise, the net daily flow volume to the north at site CU2 was 140 times greater than at site WN2 (table 3).

Bales and Skrobialowski (1994) reported that daily mean flow at West Neck Creek was to the south 64 percent of the time during 1991-92, which is comparable to the amount of time (68 percent) flow was to the south at site WN2 during this study (fig. 3). Flow at site WN2 was between $100 \mathrm{ft}^{3} / \mathrm{s}$ to the south and $-100 \mathrm{ft}^{3} / \mathrm{s}$ to the north nearly 90 percent of the time 


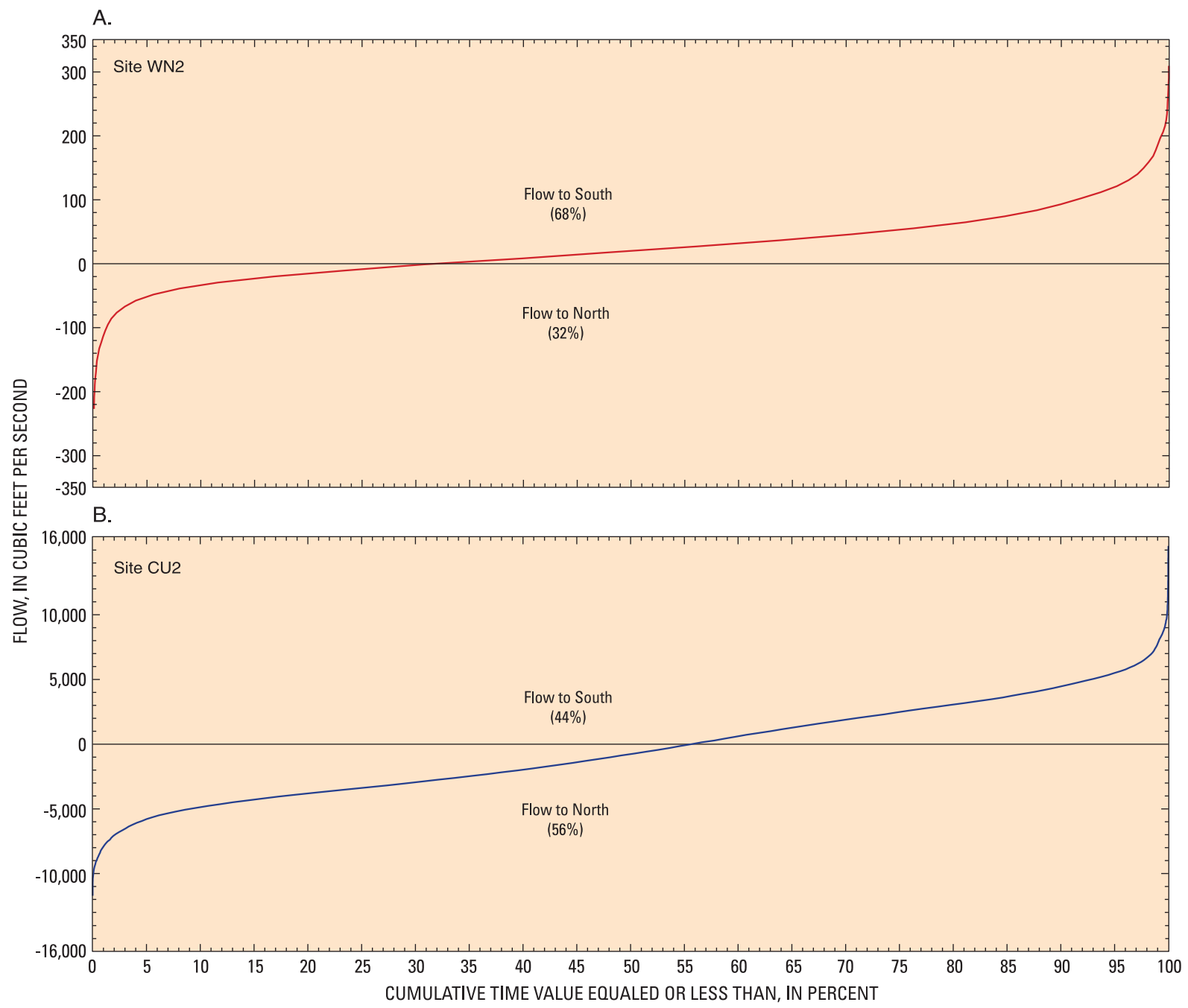

Figure 3. Cumulative frequency distribution of flows at (A) West Neck Creek (site WN2) and (B) Coinjock (site CU2) from March 1, 1998, to February 28, 1999. 
Table 3. Summary of flow characteristics at West Neck Creek (site WN2) and Coinjock (site CU2) based on 15-minute interval measurements made from March 1, 1998, to February 28, 1999

$\left[\mathrm{ft}^{3} / \mathrm{s}\right.$, cubic feet per second; $\mathrm{ft}^{3}$, cubic feet. Positive values are to the south; negative (-) values are to the north. Locations of sites are shown in figure 1]

\begin{tabular}{|c|c|c|}
\hline Flow characteristics & Site WN2 & Site CU2 \\
\hline \multicolumn{3}{|c|}{ All 15-minute interval flow } \\
\hline Mean, in $\mathrm{ft}^{3} / \mathrm{s}$ & 24.8 & -448 \\
\hline Median, in $\mathrm{ft}^{3} / \mathrm{s}$ & 20.1 & -767 \\
\hline Maximum observed, in $\mathrm{ft}^{3} / \mathrm{s}$ & 313 & 15,300 \\
\hline Minimum observed, in $\mathrm{ft}^{3} / \mathrm{s}$ & -227 & $-11,700$ \\
\hline Number of measurements analyzed & 34,407 & 32,991 \\
\hline \multicolumn{3}{|c|}{ Common daily net flow volume ${ }^{\mathrm{a}}$} \\
\hline Mean, in $\mathrm{ft}^{3}$ & $2.11 \times 10^{6}$ & $3.66 \times 10^{7}$ \\
\hline Median, in $\mathrm{ft}^{3}$ & $1.77 \times 10^{6}$ & $-4.69 \times 10^{7}$ \\
\hline Maximum observed, in $\mathrm{ft}^{3}$ & $1.83 \times 10^{7}$ & $6.34 \times 10^{8}$ \\
\hline Minimum observed, in $\mathrm{ft}^{3}$ & $-9.88 \times 10^{6}$ & $-7.31 \times 10^{8}$ \\
\hline Number of measurements analyzed & 348 & 348 \\
\hline \multicolumn{3}{|c|}{ All days for which net flow volume was to the south } \\
\hline Mean, in $\mathrm{ft}^{3}$ & $3.39 \times 10^{6}$ & $1.87 \times 10^{8}$ \\
\hline Median, in $\mathrm{ft}^{3}$ & $2.50 \times 10^{6}$ & $1.60 \times 10^{8}$ \\
\hline Maximum observed, in $\mathrm{ft}^{3}$ & $1.83 \times 10^{7}$ & $6.34 \times 10^{8}$ \\
\hline Minimum observed, in $\mathrm{ft}^{3}$ & $1.40 \times 10^{4}$ & $9.44 \times 10^{5}$ \\
\hline Number of measurements analyzed & 271 & 157 \\
\hline \multicolumn{3}{|c|}{ All days for which net flow volume was to the north } \\
\hline Mean, in $\mathrm{ft}^{3}$ & $-1.59 \times 10^{6}$ & $-2.23 \times 10^{8}$ \\
\hline Median, in $\mathrm{ft}^{3}$ & $-9.22 \times 10^{5}$ & $-2.13 \times 10^{8}$ \\
\hline Maximum observed, in $\mathrm{ft}^{3}$ & $-9.88 \times 10^{6}$ & $-7.31 \times 10^{8}$ \\
\hline Minimum observed, in $\mathrm{ft}^{3}$ & $-9.61 \times 10^{3}$ & $-8.43 \times 10^{6}$ \\
\hline Number of measurements analyzed & 93 & 191 \\
\hline
\end{tabular}

${ }^{\mathrm{a}}$ Data recorded simultaneously at all sites.

(fig. 3), and typically double-peaked over a 24-hour period due to tidal influence (fig. 4).

Flow was much greater at site CU2 than at site WN2 and showed less distinct tidal characteristics (fig. 4). Flow at site CU2 was affected more by wind than by tides and, therefore, was less predictable. Flow at site CU2 was between $6,000 \mathrm{ft}^{3} / \mathrm{s}$ to the south and $-6,000 \mathrm{ft}^{3} / \mathrm{s}$ to the north about 90 percent of the time and between 0 and $-6,000 \mathrm{ft}^{3} / \mathrm{s}$ to the north about 50 percent of the time (fig. 3 ).

Daily net flow volume was calculated as the sum of the instantaneous flow volumes (measured 15-minute interval flow, in cubic feet per second, integrated over time) for each day at sites WN2 and CU2. Days of missing record (fewer than 5 percent of the days) were assigned a null value that did not increase or decrease the cumulative flow volume. For the period March 1, 1998, to February 28, 1999, the cumulative flow volume at site WN2 was $7.69 \times 10^{8} \mathrm{ft}^{3}$ with a net flow to the south (fig. 5). For the same period, the cumulative flow volume at site $\mathrm{CU} 2$ was $-1.33 \times 10^{10} \mathrm{ft}^{3}$ with a net flow to the north (fig. 6).

Winds associated with rainfall events make it difficult to determine the effects of precipitation alone on daily flow volumes at sites WN2 and CU2. Data from weather station WS1, approximately 8 mi north of site WN2, and weather station WS2, approximately $15 \mathrm{mi}$ west of site CU2 (fig. 1), were summarized for the days having the largest precipitation totals (table 4) during the study period (National Oceanic and Atmospheric Administration, 1998, 1999). The total rainfall of $43.09 \mathrm{in}$. at site WS1 for the study period was representative of the long-term average (January 1979 to May 1998) of about 45 inches per year (in/yr). The precipitation totals given in table 4 are for the previous 24 hours for each of the dates shown. When 


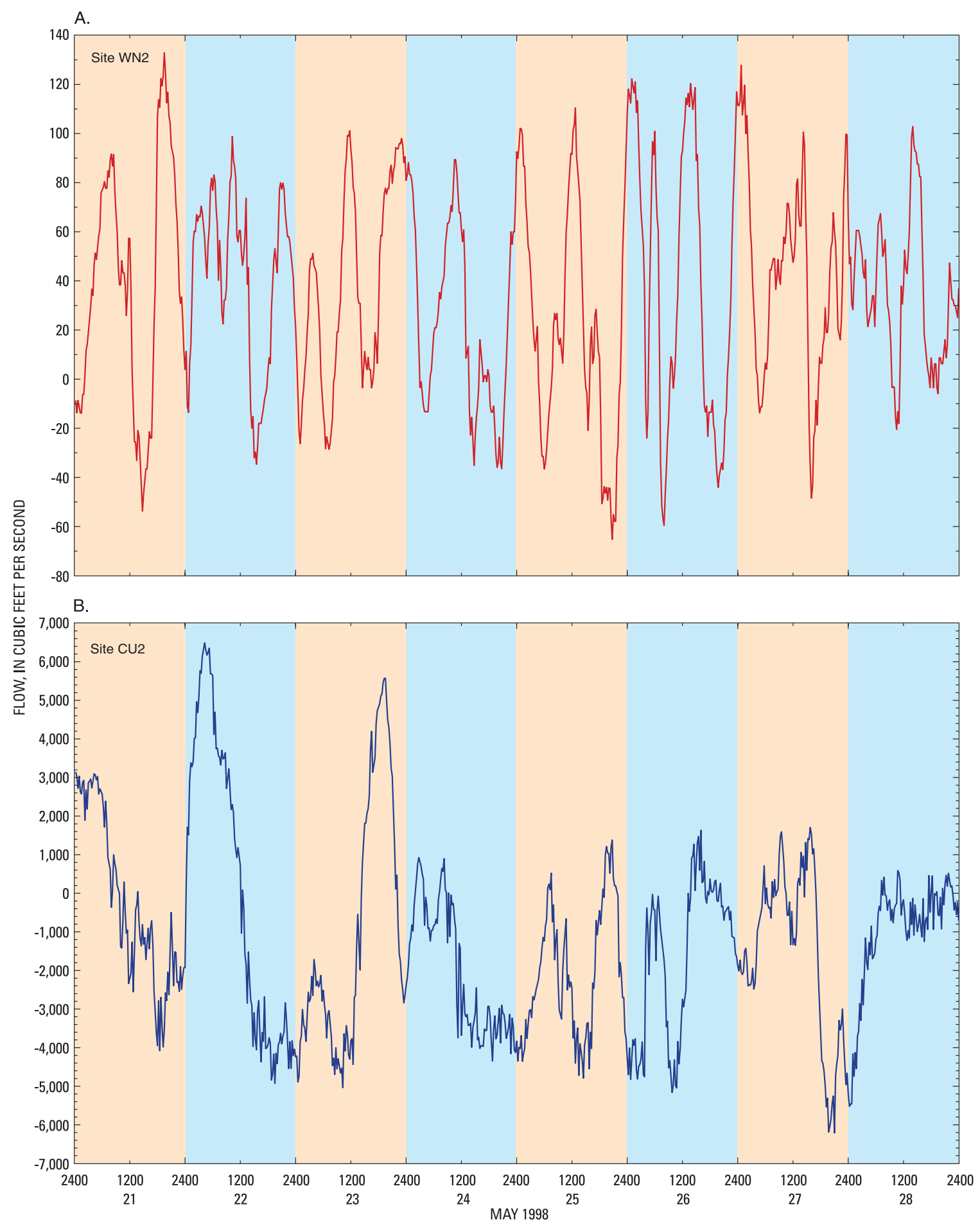

Figure 4. Flow at (A) West Neck Creek (site WN2) and (B) Coinjock (site CU2), May 21-28, 1998. 

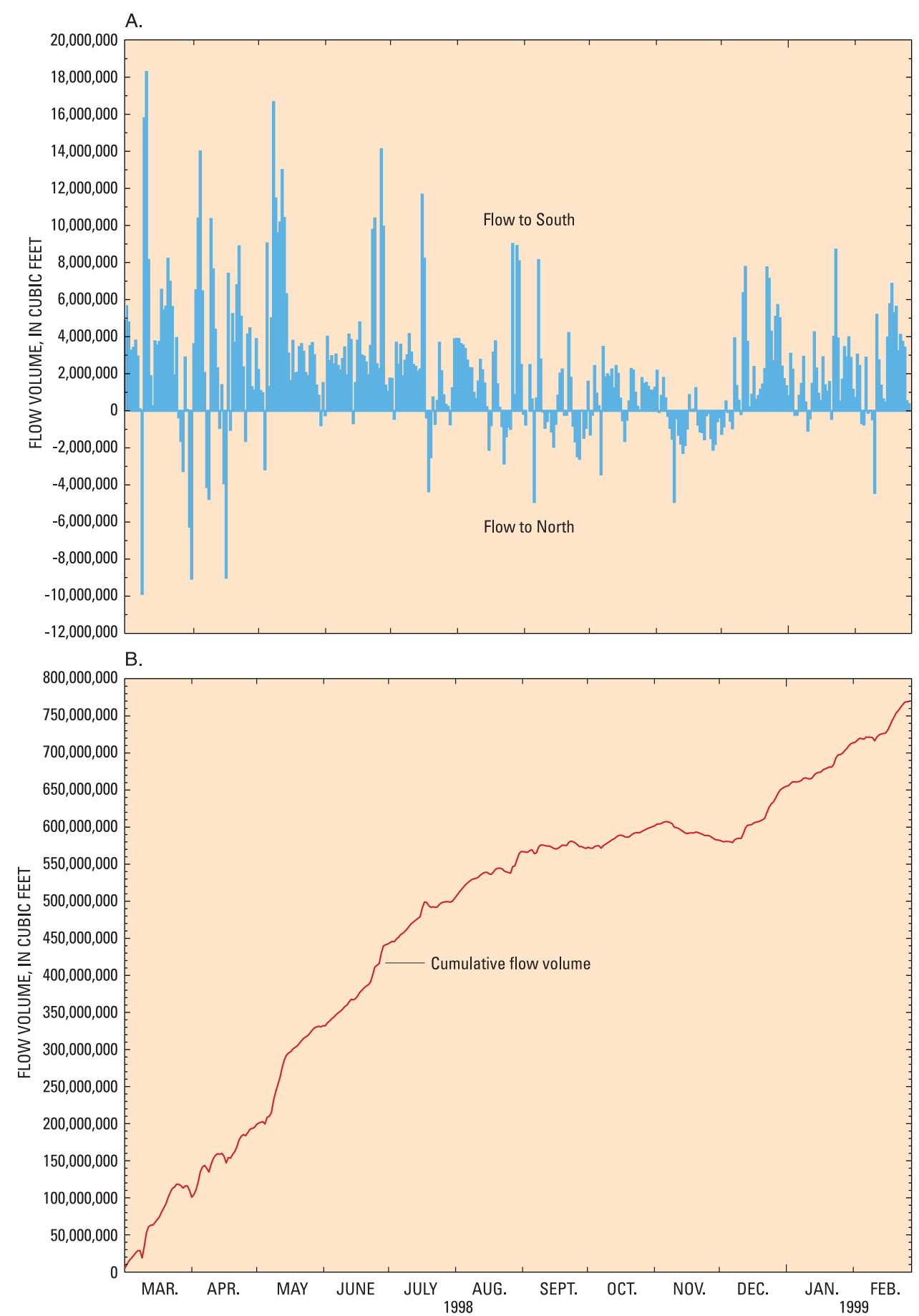

Figure 5. (A) Daily net flow volume and (B) cumulative flow volume at West Neck Creek (site WN2) from March 1, 1998, to February 28, 1999. 

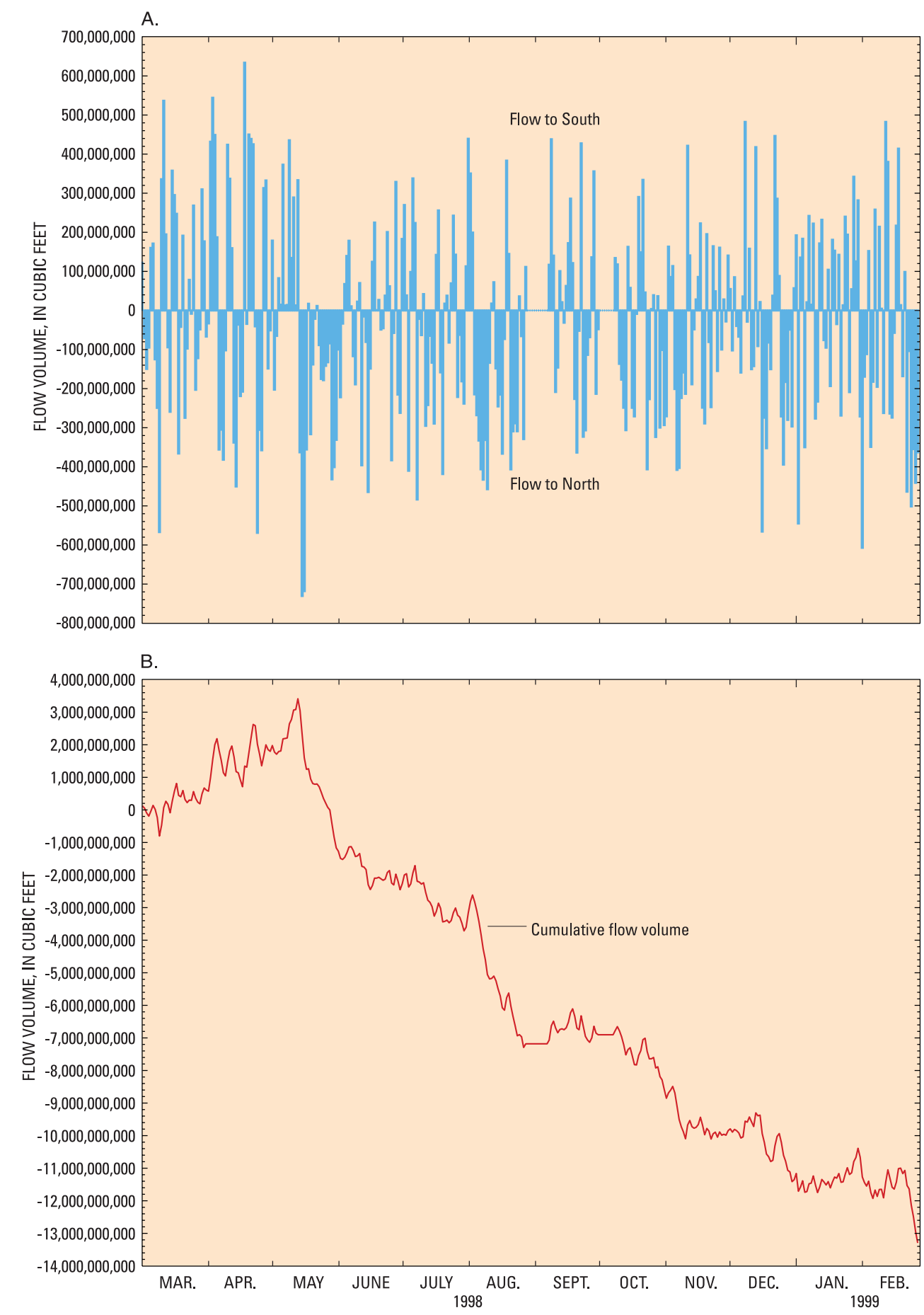

Figure 6. (A) Daily net flow volume and (B) cumulative flow volume at Coinjock (site CU2) from March 1, 1998, to February 28, 1999. 
Table 4. Largest precipitation events and associated winds and daily net flows at West Neck Creek (site WN2) and Coinjock (site CU2)

[mph, miles per hour; $\mathrm{ft}^{3}$, cubic feet; - , no data. Positive values are to the south; negative (-) values are to the north]

\begin{tabular}{|c|c|c|c|c|c|c|c|c|}
\hline \multirow[b]{2}{*}{ Date } & \multirow{2}{*}{$\begin{array}{c}\text { Daily } \\
\text { average } \\
\text { wind } \\
\text { speed } \\
\text { (mph) }\end{array}$} & \multirow[b]{2}{*}{$\begin{array}{l}\text { Prevailing } \\
\text { wind } \\
\text { direction } \\
\text { (from) }\end{array}$} & \multirow[b]{2}{*}{$\begin{array}{l}\text { 24-hour } \\
\text { precipitation } \\
\text { at WS1 } \\
\text { (inches) }\end{array}$} & \multicolumn{2}{|c|}{ WN2 } & \multirow[b]{2}{*}{$\begin{array}{c}\text { 24-hour } \\
\text { precipitation } \\
\text { at WS2 } \\
\text { (inches) }\end{array}$} & \multicolumn{2}{|c|}{ CU2 } \\
\hline & & & & $\begin{array}{c}\text { Daily net } \\
\text { flow } \\
\text { volume } \\
\left(\mathrm{ft}^{3}\right)\end{array}$ & $\begin{array}{c}\text { Percentage } \\
\text { of } \\
\text { median }\end{array}$ & & $\begin{array}{c}\text { Daily net } \\
\text { flow } \\
\text { volume } \\
\left(\mathrm{ft}^{3}\right)\end{array}$ & $\begin{array}{c}\text { Percentage } \\
\text { of } \\
\text { median }\end{array}$ \\
\hline $3-9-98$ & 17 & South & 1.69 & $-9.88 \times 10^{6}$ & $-1,071$ & 0.50 & $-5.67 \times 10^{8}$ & 266 \\
\hline $4-23-98$ & 11 & North & 1.14 & $8.87 \times 10^{6}$ & 355 & .01 & $-4.06 \times 10^{7}$ & 19 \\
\hline $7-17-98$ & 5 & West & 2.80 & $1.17 \times 10^{7}$ & 468 & 2.50 & $1.42 \times 10^{8}$ & 89 \\
\hline $8-27-98$ & 27 & East & .08 & $-9.74 \times 10^{5}$ & -106 & 1.10 & $-3.29 \times 10^{8}$ & 154 \\
\hline $8-28-98$ & 12 & Northwest ${ }^{\mathrm{a}}$ & 3.27 & $9.00 \times 10^{6}$ & 360 & .45 & $1.11 \times 10^{8}$ & 70 \\
\hline $8-30-98$ & 6 & Variable & 1.73 & $8.89 \times 10^{6}$ & 355 & 1.45 & - & - \\
\hline $8-31-98$ & 5 & Variable & 0 & $8.06 \times 10^{6}$ & 322 & 1.95 & - & - \\
\hline $10-5-98$ & 8 & North & 1.06 & $2.42 \times 10^{6}$ & 97 & 0 & - & - \\
\hline
\end{tabular}

${ }^{\mathrm{a}}$ Winds prevailed from the south and southwest August 23-25, 1998, and from the east August 26-27, 1998.

precipitation totals were greater than 1 in., net flows at site WN2 increased relative to the median flow to the north or south at the site (table 4). Such a response was not evident at site CU2 where the largest daily precipitation totals did not necessarily produce the highest daily net flows during the study period. No rainfall occurred during most of the days having the greatest net flow (table 5).

Prevailing (northerly) winds and daily average wind speeds greater than $9 \mathrm{mph}$ were associated with flow to the south at sites WN2 and CU2 (table 5). Conversely, prevailing winds from the south-southwest were associated with increased flow to the north at these sites. From March 1, 1998, to January 3, 1999, the wind was from the southwest 22 percent of the time and from the north 15 percent of the time (fig. 7A). This is consistent with long-term wind patterns observed during January 1979 through May 1998 when winds were mostly from the southwest or from the north or northeast (fig. 7C).

Table 5. Highest daily net flow volumes at West Neck Creek (site WN2) and Coinjock (site CU2) and associated precipitation and winds

$\left[\mathrm{ft}^{3}\right.$, cubic feet; mph, miles per hour. Positive values are to the south; negative (-) values are to the north]

\begin{tabular}{ccccccc}
\hline $\begin{array}{c}\text { Site } \\
\text { (fig. 1) }\end{array}$ & Date & $\begin{array}{c}\text { Daily net flow } \\
\text { volume } \\
\text { (ft }^{\mathbf{3}} \text { ) }\end{array}$ & $\begin{array}{c}\text { 24-hour } \\
\text { precipitation } \\
\text { (inches) }\end{array}$ & $\begin{array}{c}\text { Prevailing } \\
\text { wind } \\
\text { direction } \\
\text { (from) }\end{array}$ & $\begin{array}{c}\text { Daily } \\
\text { average } \\
\text { wind } \\
\text { speed } \\
\text { (mph) }\end{array}$ \\
\hline & $3-10-98$ & $1.58 \times 10^{7}$ & 0 & 0 & Northwest & 17 \\
& $3-11-98$ & $1.83 \times 10^{7}$ & 0 & 0 & Northwest & 16 \\
WN2 & $5-9-98$ & $1.66 \times 10^{7}$ & .55 & Trace & Northwest & 15 \\
& $3-9-98$ & $-9.88 \times 10^{6}$ & 1.69 & .50 & South & 17 \\
& $4-1-98$ & $-9.06 \times 10^{6}$ & 0 & 0 & South & 15 \\
& $4-17-98$ & $-9.01 \times 10^{6}$ & 0 & 0 & Southwest & 15 \\
\hline & $3-11-98$ & $5.36 \times 10^{8}$ & 0 & 0 & Northwest & 16 \\
& $4-3-98$ & $5.44 \times 10^{8}$ & 0 & 0 & Northeast & 9 \\
& $4-18-98$ & $6.34 \times 10^{8}$ & 0 & 0 & Northeast & 13 \\
& $4-24-98$ & $-5.69 \times 10^{8}$ & 0 & 0 & Southwest & 9 \\
& $5-15-98$ & $-3.63 \times 10^{8}$ & 0 & 0 & Southwest & 4 \\
& $5-16-98$ & $-7.31 \times 10^{8}$ & 0 & 0 & Southwest & 5 \\
\hline
\end{tabular}


A.
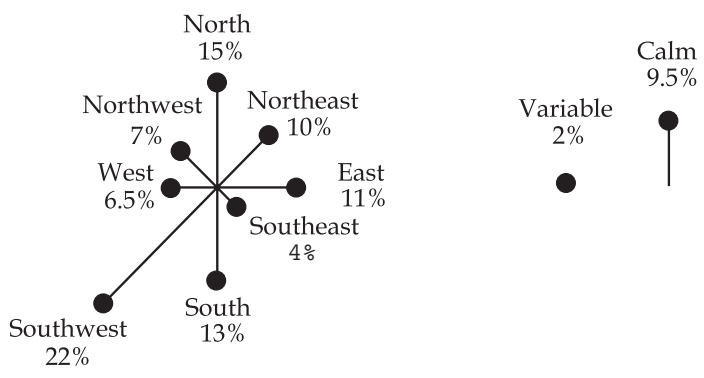

Study period (March 1, 1998, to January 3, 1999

C.

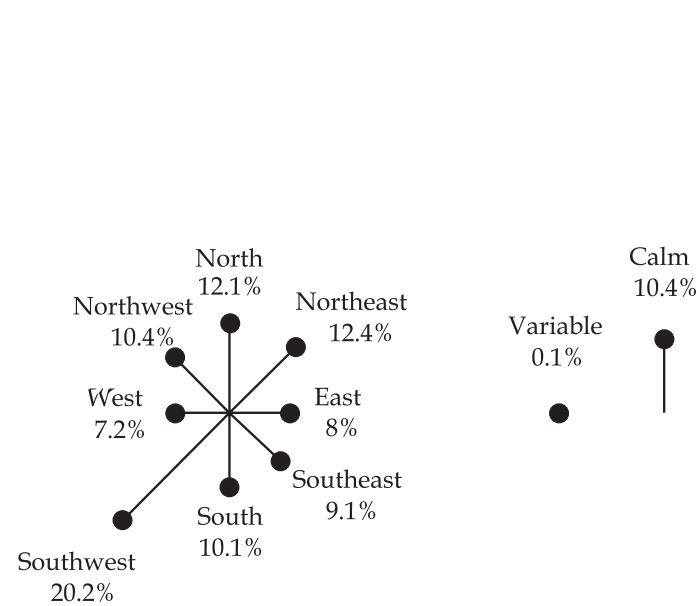

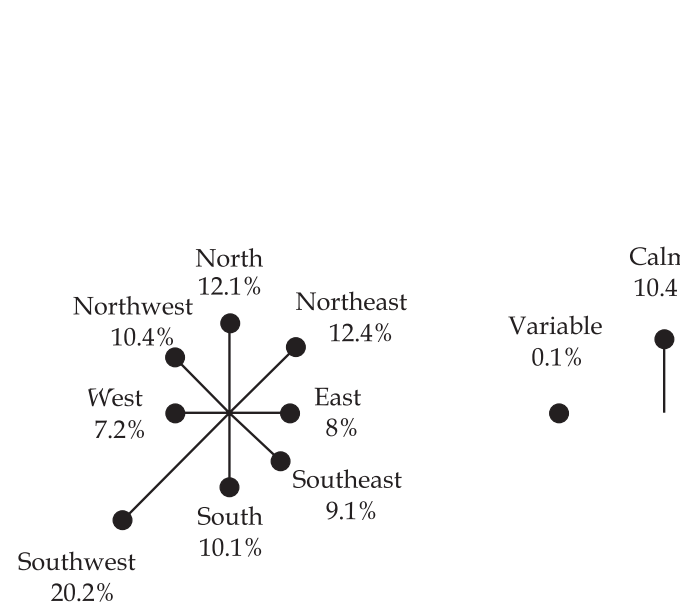

B.

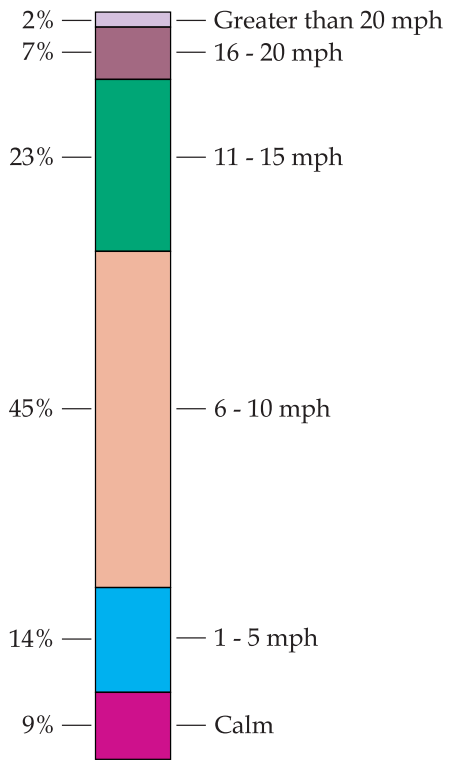

D.

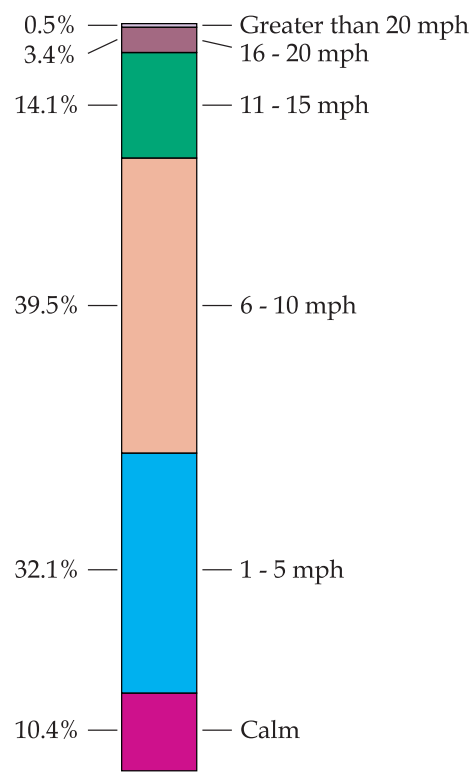

Long-term period (January 1979 to May 1998)

Figure 7. (A) Percentage of time wind blew from indicated direction and (B) frequency of occurrence of measured hourly wind speed at site WS1 from March 1, 1998, to January 3, 1999, and (C) percentage of time wind blew from indicated direction and (D) frequency of occurrence of measured hourly wind speed at site WS1 for the period January 1979 through May 1998. 
At site WN2, the largest flows to the south were associated with wind speeds averaging more than $15 \mathrm{mph}$ from the northwest, and flows to the north were associated with wind speeds averaging more than $15 \mathrm{mph}$ from the south and southwest (table 5). When winds prevailed from the north, waters in the Chesapeake Bay presumably were pushed southward against the land in Lynnhaven Bay (fig. 1), and water in Currituck Sound was pushed south reducing the elevation at the north end, thus creating a slope in the water-level surface causing flow to move toward the south through London Bridge Creek and Canal No. 2 to West Neck Creek.
During April 21-29, 1998 (a period typical of spring conditions), flow was predominantly to the south at site WN2, regardless of wind direction (fig. 8A); however, winds from the west-southwest to the east-southeast were associated with the only time that flow was to the north at site WN2 during this period. Generally, this same pattern also was present during August 17-25, 1998 (a period typical of summer conditions; fig. 8B). Flow was most likely to the north at site WN2 when winds were from the south to southwest, although winds from this direction do not always coincide with flows to the north because of fairly strong tidal effects at the site.
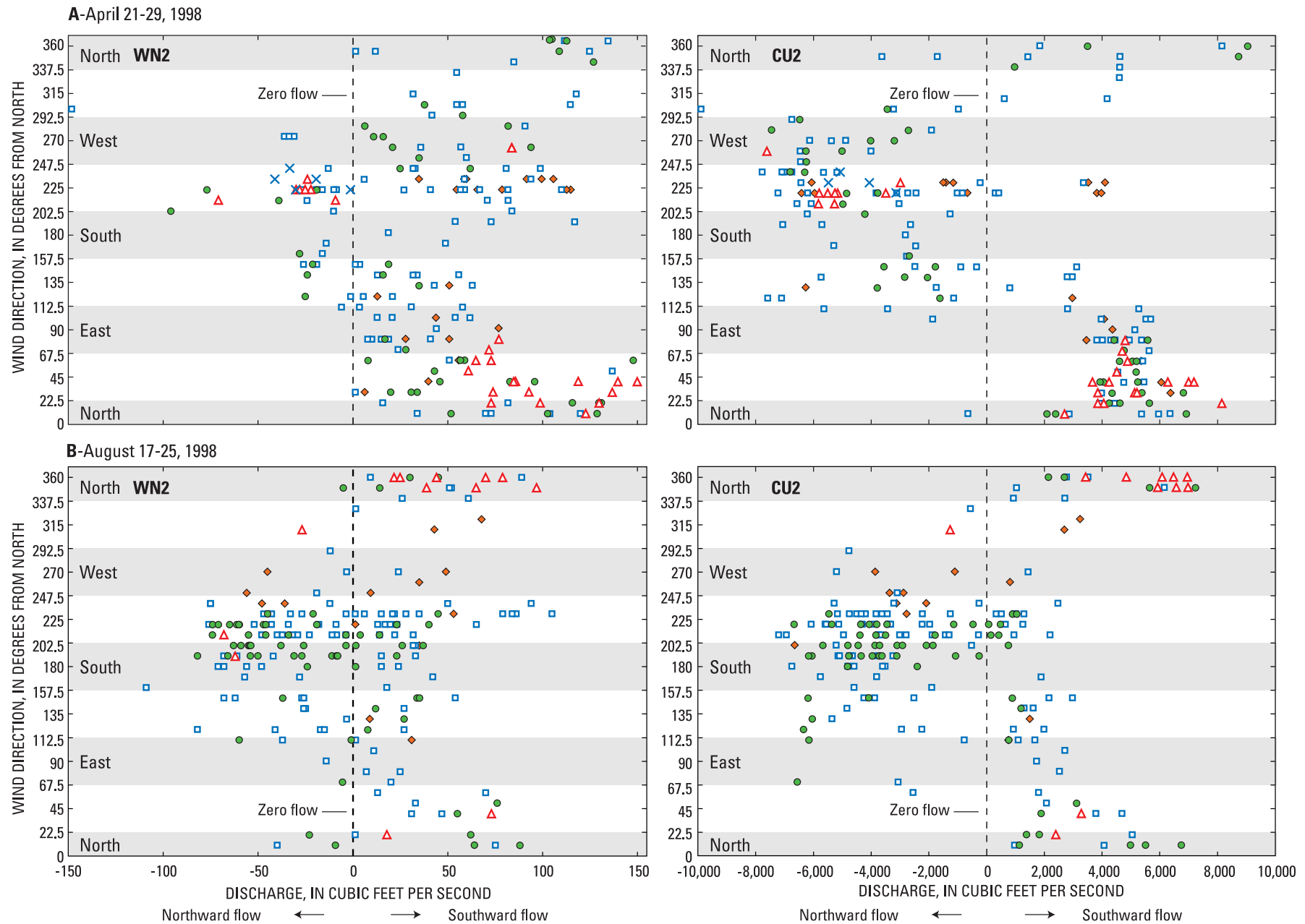

$$
\begin{array}{cc} 
& \text { EXPLANATION } \\
\diamond & 1-5 \text { MILES PER HOUR } \\
\square & 6-10 \text { MILES PER HOUR } \\
\circ & 11-15 \text { MILES PER HOUR } \\
\Delta 16-20 \text { MILES PER HOUR } \\
\times \text { WIND SPEED GREATER THAN } \\
20 \text { MILES PER HOUR }
\end{array}
$$

Figure 8. Relation of hourly flow to hourly wind direction at West Neck Creek (site WN2) and Coinjock (site CU2) for the periods (A) April 21-29, 1998, and (B) August 17-25, 1998. 
Winds from the south and west forced waters from the North River into the AIWW (fig. 1), resulting in flow to the north at site CU2. Likewise, when winds were from the west-northwest to the east-northeast, flow was almost always to the south (fig. 8). Flows at site CU2 were seldom to the south when winds were from the south (fig. 8), unlike conditions at site WN2. A stronger association between wind direction and flow direction occurred at site CU2 than at site WN2.

On June 9, 1998, two discharge measurements of $-16,400 \mathrm{ft}^{3} / \mathrm{s}$ and $-22,500 \mathrm{ft}^{3} / \mathrm{s}$ to the north were made at site CU4 in Currituck Sound. The average of these measurements is $-19,500 \mathrm{ft}^{3} / \mathrm{s}$ to the north-more than eight times the flow to the north at site CU2 during the time of these measurements. Simultaneous measurements of discharge at sites CU4 and CU2 may provide insight into the relation of flows at the two sites. A flow model of Currituck Sound would provide needed detail on flow patterns in and out of the sound, as well as flow within the sound.

\section{SALINITY CHARACTERISTICS}

Salinity characteristics identified during this study include spatial patterns, seasonal variations in salinity, and effects of flow and wind on salinity at all six study sites. Salt loads at sites WN2 and CU2 also are presented for the study period.

The magnitude of prevailing seasonal and eventdriven conditions, such as winds and tides, are associated with variations in salinity within the sound. Events of low magnitude are associated with little variation in salinity along the northern and southern boundaries of the sound. Conversely, events of greater magnitude (strong winds and large tide variations) tend to increase salinity variations along the northern and southern boundaries of the sound. Salinity variations remained the lowest within the central portion of the sound (site CU1) throughout the study period.

\section{Spatial Patterns}

The mean and median salinities at all sites except site CU4 were below 3.5 ppt, 10 percent of typical ocean salinity and the level at which adverse effects can occur in freshwater fish reproduction (table 6; Kornegay, 1989). The maximum salinity observed at all sites exceeded $3.5 \mathrm{ppt}$ (fig. 9). The largest ranges in salinity were observed at sites WN2 and CU4 (17.4 and $20.0 \mathrm{ppt}$, respectively). These large ranges may be due to proximity to a salt source. Interestingly, site AC1 had the third largest salinity range (7.1 ppt), which may indicate that the Albemarle and Chesapeake Canal is a source of salt to Currituck Sound. The two sites in the interior of Currituck Sound (sites CU1 and CU3) had the smallest ranges in salinity (3.1 and $3.2 \mathrm{ppt}$, respectively).

The highest salinities were at sites WN2 and CU4 (table 6; fig. 9); however, the lowest salinities also were at site WN2 and at site AC1. Salinity at sites AC1, CU1, CU2, and CU3 was always less than or equal to $7.2 \mathrm{ppt}$ (table 6). Salinity was less than or equal to $3.5 \mathrm{ppt}$ at all study sites more than 80 percent of the time, except at site CU4 where salinities were less than or equal to $3.5 \mathrm{ppt}$ less than 50 percent of the time (fig. 10). Salinity at site CU4 is trimodal-less than

Table 6. Salinity characteristics at the Currituck Sound and tributary study sites based on measurements made from March 1, 1998, to February 28, 1999

[ppt, parts per thousand]

\begin{tabular}{|c|c|c|c|c|c|c|c|c|c|c|}
\hline \multirow[b]{2}{*}{$\begin{array}{l}\text { Site } \\
\text { (fig. 1) }\end{array}$} & \multicolumn{5}{|c|}{ All measurements (ppt) } & \multicolumn{5}{|c|}{ Common measurements $^{a}$ (ppt) } \\
\hline & Mean & Median & $\begin{array}{c}\text { Maximum } \\
\text { observed }\end{array}$ & $\begin{array}{l}\text { Minimum } \\
\text { observed }\end{array}$ & $\begin{array}{c}\text { Number of } \\
\text { measure- } \\
\text { ments } \\
\text { analyzed }\end{array}$ & Mean & Median & $\begin{array}{c}\text { Maximum } \\
\text { observed }\end{array}$ & $\begin{array}{l}\text { Minimum } \\
\text { observed }\end{array}$ & $\begin{array}{c}\text { Number of } \\
\text { measure- } \\
\text { ments } \\
\text { analyzed }\end{array}$ \\
\hline WN2 & 2.1 & 0.7 & 17.5 & 0.1 & 35,040 & 2.1 & 0.7 & 17.5 & 0.1 & 32,889 \\
\hline $\mathrm{AC} 1$ & 1.6 & 1.3 & 7.2 & .1 & 35,040 & 1.6 & 1.4 & 7.2 & .1 & 32,889 \\
\hline CU1 & 1.3 & 1.0 & 3.6 & .5 & 35,040 & 1.3 & 1.0 & 3.6 & .5 & 32,889 \\
\hline CU2 & 2.0 & 1.3 & 5.1 & .5 & 35,040 & 2.0 & 1.3 & 5.1 & .5 & 32,889 \\
\hline CU3 & 1.6 & 1.6 & 3.7 & .5 & 34,153 & 1.6 & 1.7 & 3.7 & .5 & 32,889 \\
\hline CU4 & 3.6 & 4.2 & 20.3 & .3 & 33,196 & 3.6 & 4.1 & 20.3 & .3 & 32,889 \\
\hline
\end{tabular}

${ }^{\mathrm{a} D}$ Data recorded simultaneously at all sites. 

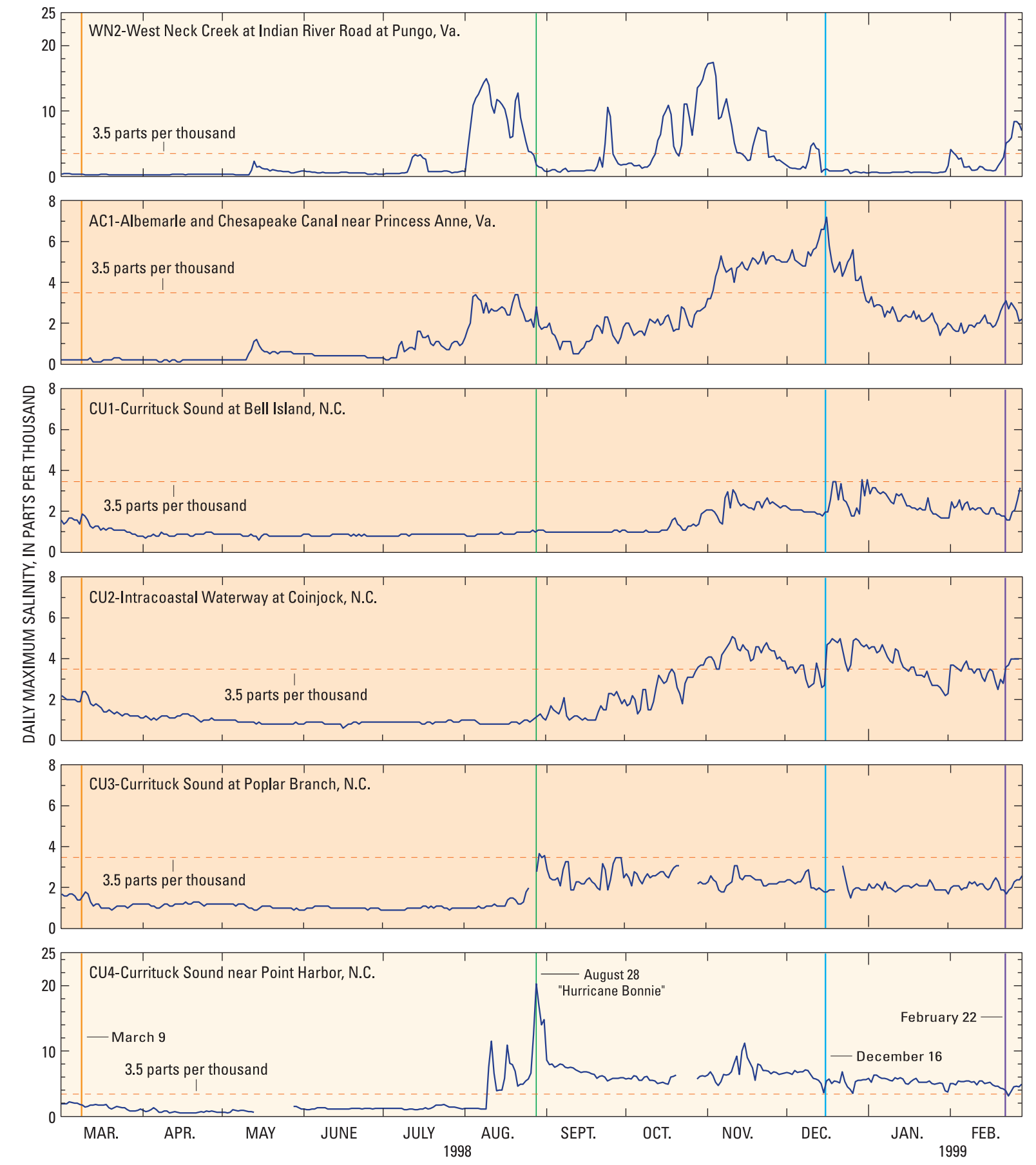

Figure 9. Daily maximum salinity at the Currituck Sound and tributary study sites from March 1, 1998, to February 28, 1999.

2 ppt about 40 percent of the time, between 2 and 8 ppt about 55 percent of the time, and greater than $8 \mathrm{ppt}$ 5 percent of the time. Salinity was less than or equal to 3.5 ppt at sites CU1 and CU3 (in Currituck Sound) nearly 100 percent of the time (99.96 and 99.82 percent, respectively), and at site $\mathrm{AC} 1$ (in the
Albemarle and Chesapeake Canal about 10 mi north of the sound) about 86 percent of the time. Salinities at sites CU2 and WN2 were less than or equal to $3.5 \mathrm{ppt}$ about 82 percent of the time (fig. 10).

The daily maximum salinity at site WN2 was less than or equal to $1 \mathrm{ppt}$ about 54 percent of the time 


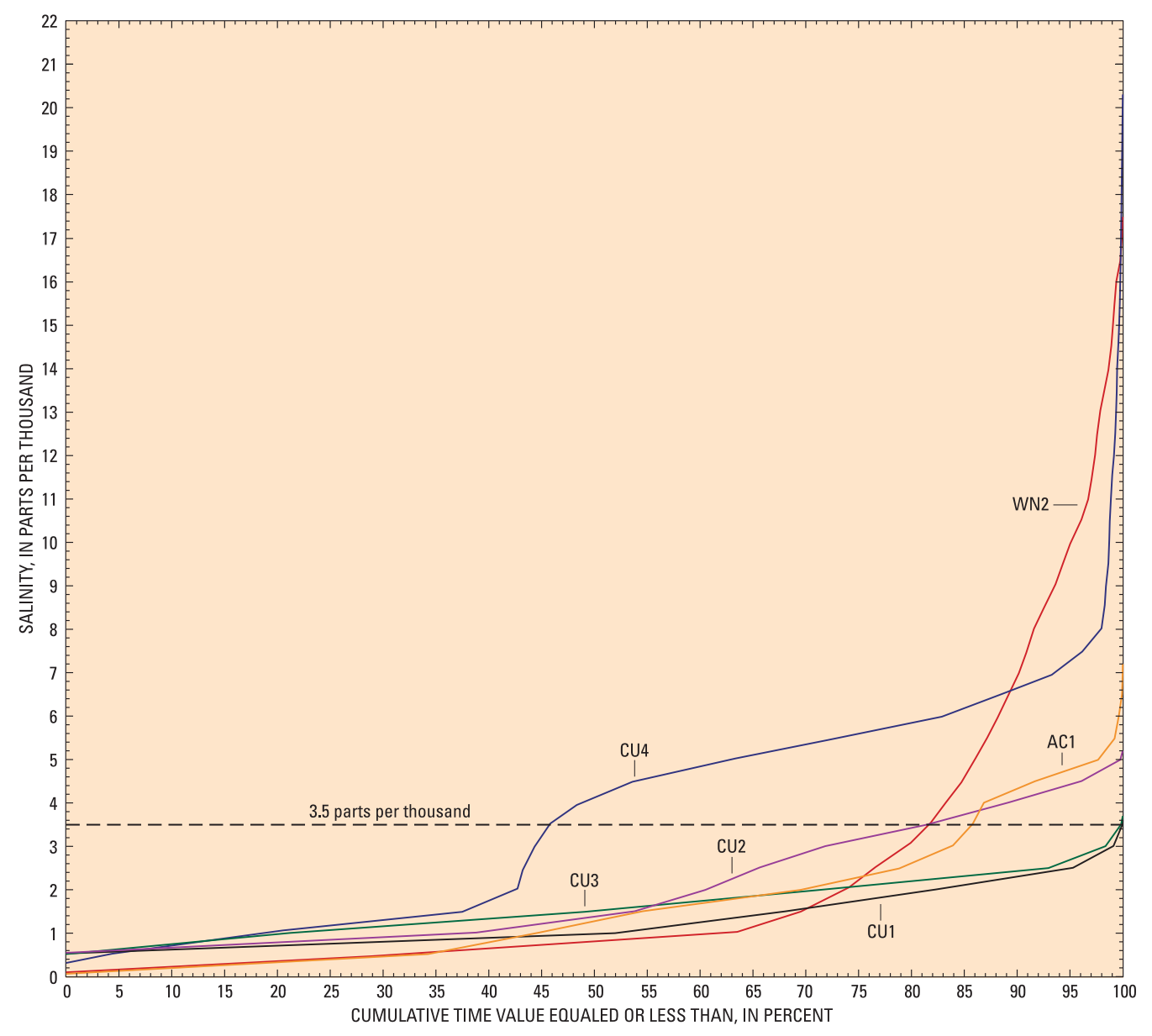

Figure 10. Cumulative frequency distribution of salinity at the Currituck Sound and tributary study sites from March 1, 1998, to February 28, 1999.

and less than or equal to $10 \mathrm{ppt}$ about 92 percent of the time. These percentages are consistent with those observed in West Neck Creek by Bales and Skrobialowski (1994; 50 and 94 percent, respectively).

During the period from the occurrence of Hurricane Bonnie (August 28, 1998) to the end of the study (February 28, 1999), daily maximum salinity at sites WN2, AC1, and CU4 exceeded daily maximum salinity at the other sites most of the time (fig. 11). Figure 11 contains the same data as figure 9 except that the comparison of daily maximum salinity is shown only for sites WN2, AC1, and CU4 for simplicity. Daily maximum salinities at the remaining sites (CU1, CU2, and CU3) were less than or equal to $5.1 \mathrm{ppt}$ (baseline shown in fig. 11). The highest salinities were observed at the sites farthest north (WN2) and farthest south (CU4). These two sites are closest to sources of seawater. During much of November and December 1998, salinity at site AC1 was higher than the salinity at site WN2 and briefly higher than the salinity at site CU4 (fig. 11), whereas salinity at site CU1 remained low (about 2 ppt; fig. 9). This suggests that the source of salt at that time may have been southward flow through Great Bridge Lock (fig. 1) rather than the northward movement of salt through Currituck Sound.

Daily maximum salinity throughout the study area differed by as much as $19.3 \mathrm{ppt}$ and as little as $0.8 \mathrm{ppt}$ during the study period. The largest spatial difference in daily maximum salinities occurred on August 28, 1998, following Hurricane Bonnie (fig. 9). The daily maximum salinity at site CU4 was $20.3 \mathrm{ppt}$ (figs. 9, 11) but only $1.0 \mathrm{ppt}$ at site CU1 (fig. 9). The smallest spatial difference in daily maximum salinities among the sites occurred on May 11, 1998, when the daily maximum salinity at site CU3 was $1.0 \mathrm{ppt}$, and the daily maximum salinity at site $\mathrm{WN} 2$ was $0.2 \mathrm{ppt}$ (fig. 9). 


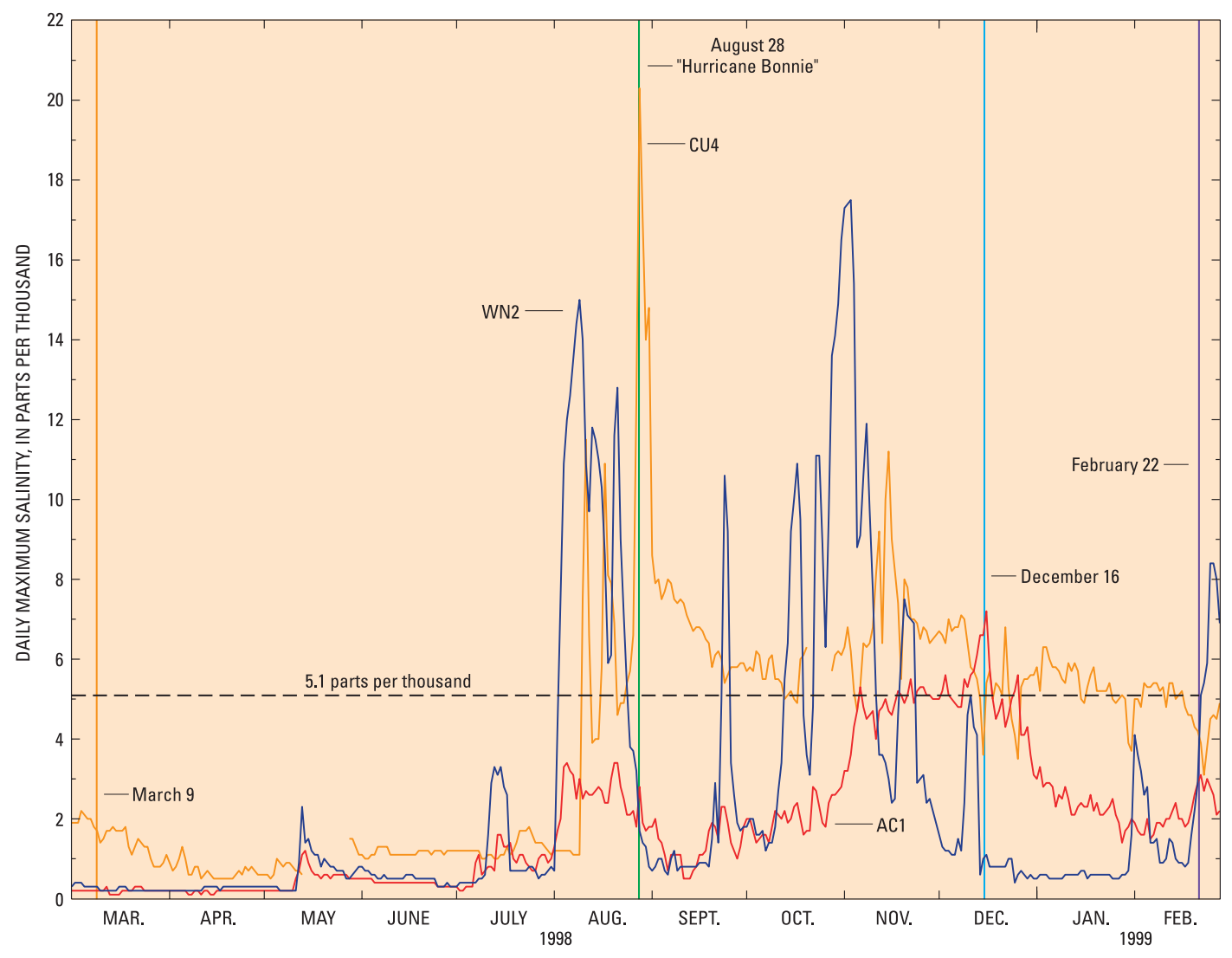

Figure 11. Comparison of daily maximum salinity at sites WN2, AC1, and CU4 from March 1, 1998, to February 28, 1999.

On June 9, 1998, salinity measurements were made along three transects beginning at sites CU1, CU3, and CU4 (fig. 12; table 7). These measurements were made to compare data from shore-based monitoring sites to conditions across the sound. Little lateral or vertical variations in salinity were observed (fig. 12; table 7). On this date, a salt gradient was observed that decreased from the southernmost site (CU4) to the northernmost site (CU1) within the sound, implying a salt source from the south (Albemarle Sound). 

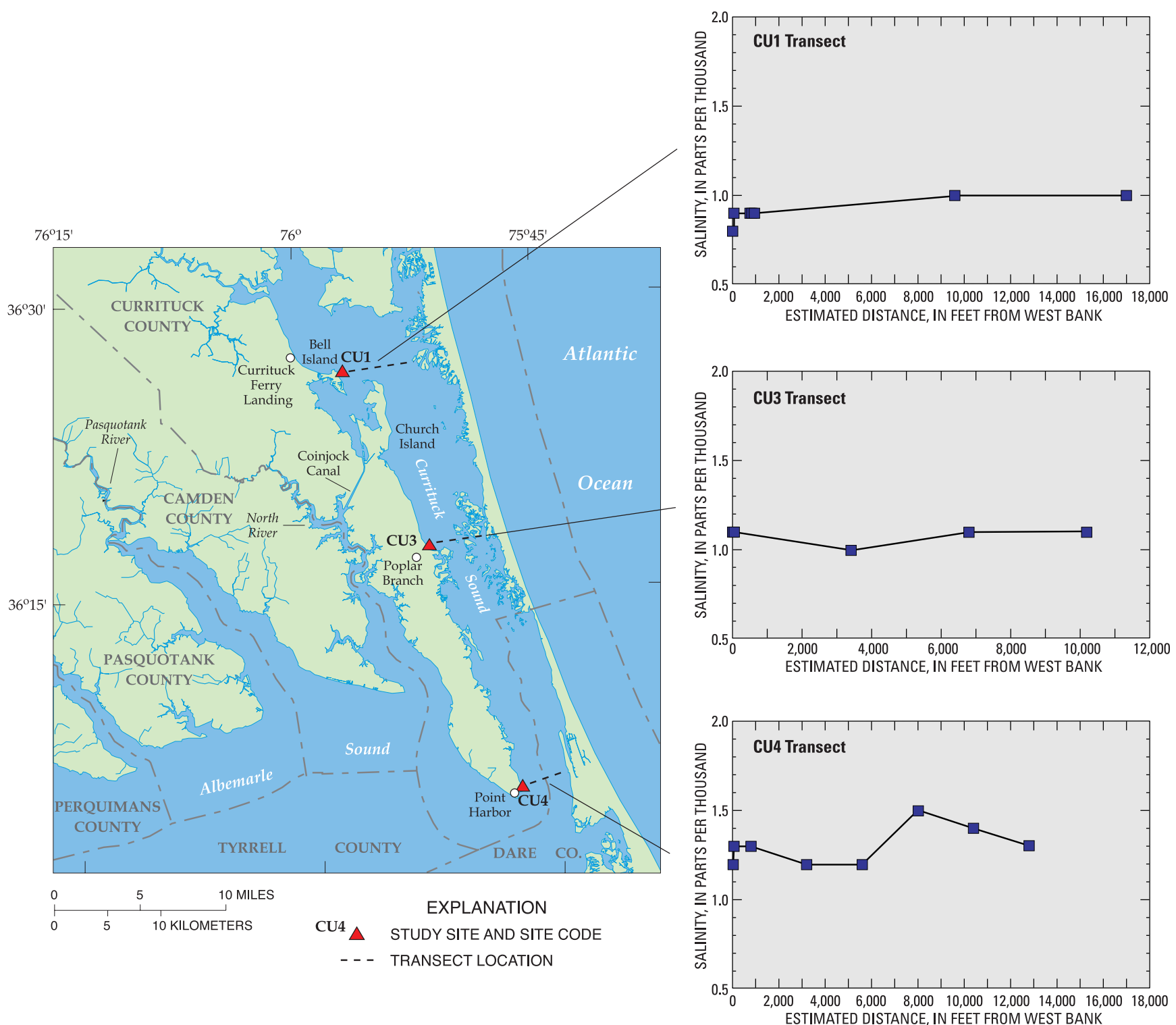

Figure 12. Locations of transects and salinity profile data at selected Currituck Sound study sites, June 9, 1998. 
Table 7. Selected water-quality values measured along three transects in Currituck Sound, June 9, 1998

[ft, feet; $\mu \mathrm{S} / \mathrm{cm}$, microsiemens per centimeter at $25^{\circ} \mathrm{C}$; ppt, parts per thousand; ${ }^{\circ} \mathrm{C}$, degrees Celsius; $\mathrm{mg} / \mathrm{L}$, milligrams per liter. Locations of transects are shown in figure 12]

\begin{tabular}{|c|c|c|c|c|c|c|c|c|c|}
\hline $\begin{array}{l}\text { Estimated } \\
\text { distance } \\
\text { from west } \\
\text { bank } \\
\text { (ft) }\end{array}$ & Time & $\begin{array}{c}\text { Sam- } \\
\text { pling } \\
\text { depth } \\
\text { (ft) }\end{array}$ & $\begin{array}{c}\text { Specific } \\
\text { conduc- } \\
\text { tance } \\
(\mu \mathrm{S} / \mathrm{cm})\end{array}$ & $\begin{array}{l}\text { pH } \\
\text { (stan- } \\
\text { dard } \\
\text { units) }\end{array}$ & $\begin{array}{l}\text { Salinity } \\
\text { (ppt) }\end{array}$ & $\begin{array}{l}\text { Water } \\
\text { temper- } \\
\text { ature } \\
\left({ }^{\circ} \mathrm{C}\right)\end{array}$ & $\begin{array}{l}\text { Dissolved } \\
\text { oxygen } \\
\text { (percent } \\
\text { saturation) }\end{array}$ & $\begin{array}{c}\text { Dissolved } \\
\text { oxygen } \\
\text { (mg/L) }\end{array}$ & $\begin{array}{c}\text { Recorded } \\
\text { instan- } \\
\text { taneous } \\
\text { salinity } \\
\text { values at } \\
\text { study site } \\
\text { (ppt) }\end{array}$ \\
\hline \multicolumn{10}{|c|}{ CU1 transect } \\
\hline 50 & 1407 & 1.20 & 1700 & 9.0 & 0.9 & 23.5 & 128 & 10.9 & 0.8 \\
\hline \multirow{4}{*}{750} & 1420 & 7.10 & 1770 & 8.2 & .9 & 21.6 & 101 & 9.0 & \multirow{4}{*}{.8} \\
\hline & 1421 & 5.00 & 1770 & 8.2 & .9 & 21.7 & 104 & 9.2 & \\
\hline & 1422 & 3.00 & 1780 & 8.3 & .9 & 21.8 & 105 & 9.2 & \\
\hline & 1423 & .90 & 1770 & 8.3 & .9 & 21.8 & 105 & 9.3 & \\
\hline \multirow{3}{*}{850} & 1425 & 8.30 & 1770 & 8.1 & .9 & 21.5 & 100 & 8.9 & \multirow{3}{*}{.8} \\
\hline & 1426 & 6.30 & 1770 & 8.2 & .9 & 21.6 & 103 & 9.1 & \\
\hline & 1427 & 1.10 & 1770 & 8.2 & .9 & 21.9 & 105 & 9.3 & \\
\hline \multirow{3}{*}{950} & 1429 & 5.40 & 1770 & 8.1 & .9 & 21.2 & 95 & 8.4 & \multirow{3}{*}{.8} \\
\hline & 1430 & 3.00 & 1780 & 8.2 & .9 & 21.8 & 105 & 9.3 & \\
\hline & 1431 & 1.20 & 1780 & 8.3 & .9 & 21.8 & 105 & 9.3 & \\
\hline \multirow{2}{*}{9,600} & 1437 & 6.30 & 1780 & 8.4 & 1.0 & 21.7 & 104 & 9.2 & \multirow{2}{*}{.8} \\
\hline & 1438 & 1.00 & 1780 & 8.4 & 1.0 & 21.8 & 107 & 9.4 & \\
\hline \multirow{4}{*}{17,000} & 1444 & 6.50 & 1870 & 8.3 & 1.0 & 21.6 & 100 & 8.9 & \multirow{4}{*}{.8} \\
\hline & 1445 & 4.60 & 1890 & 8.3 & 1.0 & 21.7 & 102 & 9.0 & \\
\hline & 1446 & 2.70 & 1880 & 8.4 & 1.0 & 21.7 & 103 & 9.1 & \\
\hline & 1447 & 1.10 & 1880 & 8.3 & 1.0 & 21.7 & 102 & 9.0 & \\
\hline \multicolumn{10}{|c|}{ CU3 transect } \\
\hline \multirow{2}{*}{50} & 1243 & 3.10 & 2090 & 8.0 & 1.1 & 22.3 & 105 & 9.1 & \multirow{2}{*}{1.1} \\
\hline & 1244 & 1.20 & 2100 & 8.1 & 1.1 & 23.5 & 107 & 9.1 & \\
\hline \multirow{2}{*}{3,400} & 1253 & 1.30 & 1890 & 8.6 & 1.0 & 22.5 & 111 & 9.6 & \multirow{2}{*}{1.1} \\
\hline & 1254 & 1.20 & 1900 & 8.6 & 1.0 & 22.4 & 111 & 9.6 & \\
\hline \multirow{2}{*}{6,800} & 1257 & 4.20 & 2050 & 8.4 & 1.1 & 21.8 & 104 & 9.1 & \\
\hline & 1258 & 1.20 & 2050 & 8.4 & 1.1 & 22.9 & 104 & 8.9 & 1.1 \\
\hline 10200 & 1302 & 3.70 & 2110 & 8.1 & 1.1 & 21.5 & 96 & 8.5 & \\
\hline 10,200 & 1303 & 1.00 & 2070 & 8.2 & 1.1 & 23.0 & 101 & 8.7 & 1.1 \\
\hline & & & & & U4 trans & & & & \\
\hline 50 & 1035 & 2.20 & 2420 & 7.8 & 1.3 & 22.0 & 99 & 8.7 & 12 \\
\hline 30 & 1036 & 1.00 & 2420 & 7.8 & 1.3 & 22.1 & 99 & 8.7 & 1.2 \\
\hline & 1039 & 5.00 & 2480 & 7.8 & 1.3 & 21.8 & 99 & 8.7 & \\
\hline 800 & 1040 & 2.90 & 2450 & 7.9 & 1.3 & 22.1 & 99 & 8.6 & 1.2 \\
\hline & 1041 & 1.20 & 2440 & 7.9 & 1.3 & 22.2 & 99 & 8.7 & \\
\hline & 1045 & 6.80 & 2280 & 8.0 & 1.2 & 22.2 & 98 & 8.6 & \\
\hline 3.200 & 1046 & 4.80 & 2280 & 8.0 & 1.2 & 22.2 & 99 & 8.6 & \\
\hline 3,200 & 1047 & 2.90 & 2270 & 8.1 & 1.2 & 22.4 & 99 & 8.6 & 1.2 \\
\hline & 1048 & .90 & 2270 & 8.1 & 1.2 & 22.4 & 99 & 8.6 & \\
\hline & 1050 & 7.40 & 2310 & 8.0 & 1.2 & 22.3 & 98 & 8.6 & \\
\hline & 1051 & 5.70 & 2310 & 8.0 & 1.2 & 22.3 & 98 & 8.6 & \\
\hline 5,600 & 1052 & 4.50 & 2300 & 8.0 & 1.2 & 22.3 & 98 & 8.6 & 1.2 \\
\hline & 1053 & 3.10 & 2300 & 8.0 & 1.2 & 22.4 & 99 & 8.6 & \\
\hline & 1054 & 1.20 & 2300 & 8.0 & 1.2 & 22.5 & 99 & 8.6 & \\
\hline & 1058 & 7.90 & 2720 & 7.9 & 1.5 & 22.4 & 97 & 8.4 & \\
\hline 8000 & 1059 & 5.90 & 2720 & 7.9 & 1.5 & 22.5 & 98 & 8.5 & 12 \\
\hline 0,000 & 1100 & 3.00 & 2700 & 8.0 & 1.5 & 22.6 & 99 & 8.6 & 1.2 \\
\hline & 1101 & 1.10 & 2700 & 8.0 & 1.5 & 22.7 & 99 & 8.6 & \\
\hline & 1104 & 8.60 & 2810 & 7.8 & 1.5 & 22.4 & 95 & 8.3 & \\
\hline & 1105 & 6.20 & 2810 & 7.9 & 1.5 & 22.4 & 96 & 8.3 & \\
\hline 10,400 & 1106 & 3.70 & 2680 & 7.9 & 1.4 & 22.5 & 98 & 8.5 & 1.2 \\
\hline & 1107 & 3.40 & 2660 & 7.9 & 1.4 & 22.5 & 98 & 8.5 & \\
\hline & 1108 & 1.10 & 2630 & 7.9 & 1.4 & 22.6 & 99 & 8.5 & \\
\hline 12800 & 1109 & 2.80 & 2390 & 8.0 & 1.3 & 22.3 & 100 & 8.7 & 12 \\
\hline 12,000 & 1110 & 1.00 & 2390 & 8.0 & 1.3 & 22.3 & 100 & 8.7 & 1.2 \\
\hline
\end{tabular}




\section{Seasonal Patterns}

Daily maximum salinities in the sound generally were low from March to July 1998, but increased from August 1998 to February 1999 (fig. 9). At sites CU1, $\mathrm{CU} 2$, and CU3, salinities were low from spring through mid-summer (April-July) and then higher during the remainder of the study period (including March 1998). At sites WN2, AC1, and CU4, salinities were low from late winter through mid-summer (March-July) and generally higher from August 1998 through February 1999 (fig. 9). Bales and Skrobialowski (1994) observed high salinities during periods of sustained north to northeasterly winds during late October to early November 1991.

Additional long-term data during a nonhurricane year are needed to determine if the slow increase in salinity in the sound during August to February 1998 was a typical seasonal response or a direct result of Hurricane Bonnie, which made landfall along the North Carolina coast during the early morning hours of August 27, 1998. The increase in salinity occurred first in the south followed by subsequent increases to the north. Within the sound, increases in salinity at site CU3 preceded increases in salinity at site CU2, which in turn preceded increases in salinity at site CU1, suggesting some northward movement of salt through the sound.

Daily maximum salinities at site $\mathrm{AC} 1$ were greater than $3.5 \mathrm{ppt}$ only during November and December (figs. 9, 11). Salinity at site CU4 was less than or equal to $2 \mathrm{ppt}$ during the spring and increased, for the most part, to between 3.5 and more than $8 \mathrm{ppt}$ during the summer, fall, and winter. Salinity measured near site CU4 from January 1990 through September 1991 exhibited similar seasonal patterns, except that salinity less than 2 ppt also occurred occasionally during the winter (Garrett, 1993). Daily maximum salinity at site CU4 was greater than 8 ppt during three separate events in August (9 days) and one event in November (4 days). Occurrences on August 11, 17, and 28, 1998, were likely a result of the effects of Hurricane Bonnie (fig. 11).

\section{Effects of Flow and Wind}

Little correlation was evident between flow volume and salinity at sites WN2 and CU2 (table 8). Days when the highest flows occurred at sites WN2 and CU2 during this investigation (table 5) did not coincide with days on which the highest salinities were recorded at these sites. The highest observed salinities at site WN2, however, were associated with net flow to the south. Daily net flows at site WN2 during these events were low-less than $3.75 \times 10^{6} \mathrm{ft}^{3}$, which is equal to a daily mean flow of about $45 \mathrm{ft}^{3} / \mathrm{s}$, or approximately the mean daily net flow volume to the south (table 3). The highest observed salinities at site CU2 were associated with daily net flows ranging from $-1.6 \times 10^{8} \mathrm{ft}^{3}$ to $-3.5 \times 10^{8} \mathrm{ft}^{3}$ to the north, or daily mean flows ranging from $-1,850$ to $-4,050 \mathrm{ft}^{3} / \mathrm{s}$ to the north (fig. 3; table 3).

Northerly winds were associated with increased salinity at sites WN2 and AC1 (fig. 13A). The relation of increased salinity at site AC1 to the occurrence of northerly winds is consistent with the previous suggestion that Great Bridge Lock is a source of salt to the waters of Currituck Sound. However, the salt source from the Great Bridge Lock may be negligible because the salt is diluted as it moves into Currituck Sound through North Landing River. Conversely, northerly winds tended to lower salinity at sites CU1, CU2, CU3, and CU4 (fig. 13B). Prevailing winds from the south and southwest tended to increase salinity at sites CU2, CU3, and CU4. Conversely, these same winds tended to lower salinity at sites WN2 and AC1. Also, winds from the northwest and west were associated with increased salinity at sites CU1 and CU2 (fig. 13A).

The magnitude of change in salinity was dependent upon the length of time the wind blew from a particular direction. For example, the largest increase in salinity at site WN2 occurred during August 1-9 when winds were from the northeast (fig. 11; table 8) for the entire period and the daily maximum salinity increased $14.3 \mathrm{ppt}$. The data indicate that the longer the wind blew from a particular direction, the more salinity was affected. Another example was when the lowest spatial difference in salinity among the study sites occurred on May 11 and was preceded by 7 days of southerly winds averaging $9 \mathrm{mph}$ (May 2-8) and 3 days of northerly winds averaging $13 \mathrm{mph}$ (May 9-11). Winds from the south caused low salinity at site WN2 $(<0.3 \mathrm{ppt})$ to slowly decrease further, whereas these same winds caused low salinity at site CU3 (<1.2 ppt) to slowly increase. Conversely, winds from the north caused salinity at site WN2 to slowly increase, but caused salinity at site CU3 to slowly decrease. Typically, when winds changed direction on a daily 
Table 8. Summary of events associated with the highest daily maximum salinities at the Currituck Sound and tributary study sites from March 1, 1998, to February 28, 1999

[ppt, parts per thousand; $\mathrm{ft}^{3} / \mathrm{s}$, cubic feet per second; $\mathrm{ft}^{3}$, cubic feet; $\mathrm{mph}$, miles per hour; na, not applicable. Positive values are to the south; negative (-) values are to the north]

\begin{tabular}{|c|c|c|c|c|c|c|}
\hline $\begin{array}{c}\text { Site } \\
\text { (fig. 1) }\end{array}$ & Date & $\begin{array}{l}\text { Daily } \\
\text { maximum } \\
\text { salinity } \\
\text { (ppt) }\end{array}$ & $\begin{array}{c}\text { Daily } \\
\text { instantaneous } \\
\text { flow } \\
\text { maximum / } \\
\text { minimum } \\
\left(\mathrm{ft}^{3} / \mathrm{s}\right)\end{array}$ & $\begin{array}{c}\text { Daily } \\
\text { net } \\
\text { flow } \\
\text { volume } \\
\left(\mathrm{ft}^{3}\right)\end{array}$ & $\begin{array}{l}\text { Daily } \\
\text { average } \\
\text { wind } \\
\text { speed } \\
\text { (mph) }\end{array}$ & $\begin{array}{l}\text { Prevailing } \\
\text { wind } \\
\text { direction } \\
\text { (from) }\end{array}$ \\
\hline \multirow{7}{*}{ WN2 } & $8-8-98$ & 14.4 & $+69 /-18$ & $+2.30 \times 10^{6}$ & 8 & Northeast \\
\hline & $8-9-98$ & 15 & $+72 /-22$ & $+2.29 \times 10^{6}$ & 7 & Northeast \\
\hline & $8-20-98$ & 11.6 & $+90 /+7$ & $+3.74 \times 10^{6}$ & 8 & Northeast \\
\hline & $8-21-98$ & 12.8 & $+61 /-32$ & $+1.42 \times 10^{6}$ & 9 & Northeast \\
\hline & $11-1-98$ & 17.3 & $+36 /-25$ & $+1.08 \times 10^{6}$ & 5 & Northwest \\
\hline & $11-2-98$ & 17.4 & $+40 /-17$ & $+1.24 \times 10^{6}$ & 4 & West \\
\hline & $11-3-98$ & 17.5 & $+75 /-12$ & $+2.16 \times 10^{6}$ & 8 & Northeast \\
\hline \multirow{6}{*}{$\mathrm{AC} 1$} & $11-5-98$ & 4.7 & na / na & na & 12 & North \\
\hline & $11-6-98$ & 5.3 & na / na & na & 13 & Northwest \\
\hline & $12-15-98$ & 6.6 & na / na & na & 9 & Northeast \\
\hline & $12-16-98$ & 7.2 & na / na & na & 15 & Northwest \\
\hline & $12-18-98$ & 2.6 & na / na & na & 12 & Northwest \\
\hline & $12-19-98$ & 3.5 & na / na & na & 7 & West \\
\hline \multirow{2}{*}{ CU1 } & $12-29-98$ & 1.9 & na / na & na & 6 & North \\
\hline & $12-30-98$ & 3.6 & na / na & na & 15 & West-Northwest \\
\hline \multirow{4}{*}{ CU2 } & $11-10-98$ & 4.8 & $+1,083 /-5,059$ & $-1.59 \times 10^{8}$ & 10 & Southeast \\
\hline & $11-11-98$ & 5.1 & $+3,925 /-8,697$ & $-2.13 \times 10^{8}$ & 15 & Southwest \\
\hline & $12-18-98$ & 4.8 & $+1,617 /-5,287$ & $-2.74 \times 10^{8}$ & 12 & West-Northwest \\
\hline & $12-19-98$ & 5.0 & $-2,745 /-5,293$ & $-3.52 \times 10^{8}$ & 7 & West \\
\hline \multirow{4}{*}{ CU3 } & $8-28-98$ & 2.8 & na / na & na & 12 & Northwest \\
\hline & $8-29-98$ & 3.7 & na / na & na & 6 & Southwest \\
\hline & $9-26-98$ & 3.5 & na / na & na & 7 & South \\
\hline & $9-27-98$ & 3.5 & na / na & na & 12 & Southwest \\
\hline \multirow{7}{*}{ CU4 } & $8-10-98$ & 7.5 & na / na & na & 10 & South \\
\hline & $8-11-98$ & 11.5 & na / na & na & 8 & South \\
\hline & $8-17-98$ & 10.9 & na / na & na & 10 & Southwest \\
\hline & $8-27-98$ & 12.5 & na / na & na & 27 & East \\
\hline & 8-28-98 & 20.3 & na / na & na & 12 & Northwest $^{\mathrm{a}}$ \\
\hline & $11-14-98$ & 10.0 & na / na & na & 9 & Southwest \\
\hline & $11-15-98$ & 11.2 & na / na & na & 16 & Southwest \\
\hline
\end{tabular}

${ }^{\mathrm{a}}$ Winds prevailed from the south and southwest August 23-25, 1998, and from the east August 26-27, 1998. 
A. Increased salinity
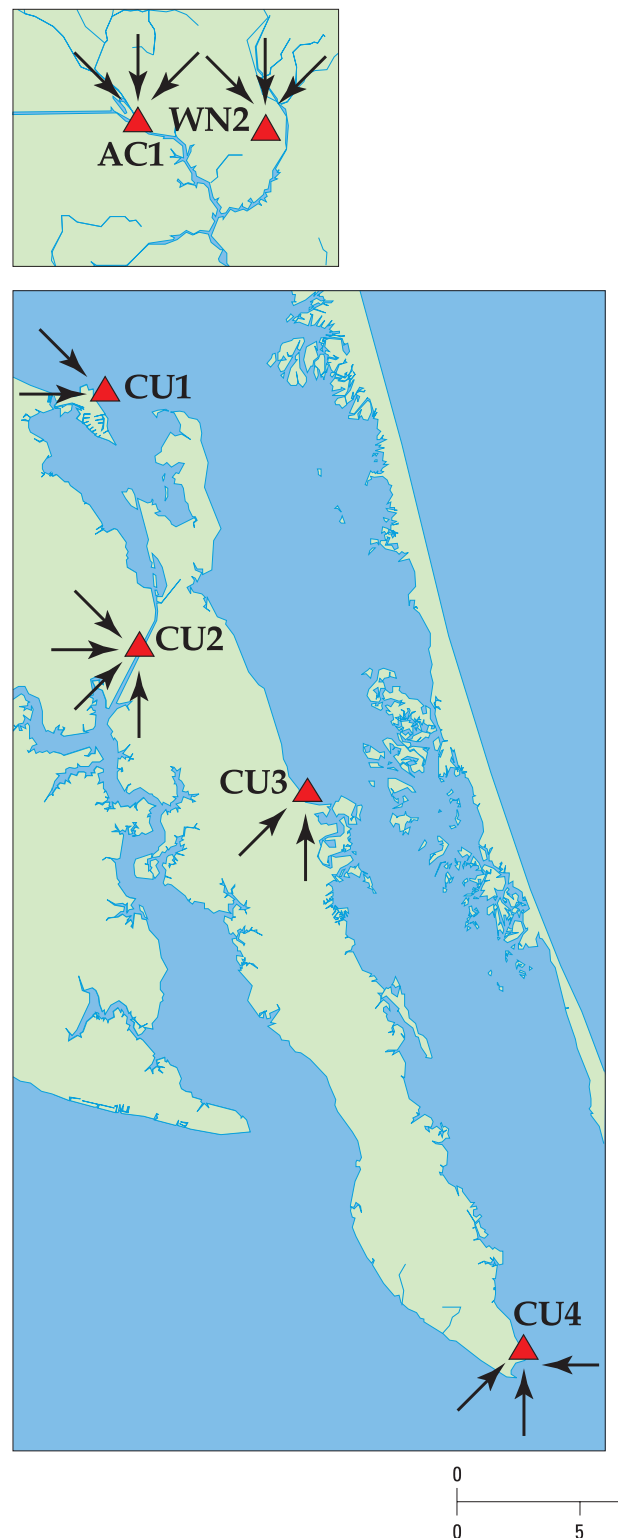

EXPLANATION

CU4 $\triangle$ STUDY SITE AND SITE CODE

$\leftarrow$ PREVAILING WIND DIRECTION

Figure 13. Prevailing wind direction resulting in $(A)$ increased salinities and $(B)$ decreased salinities at Currituck Sound and tributary study sites, March 1, 1998, to February 28, 1999.

basis, fluctuations in salinity in the sound were minimized.

Events that produced the largest daily maximum salinities were evaluated to determine the relation between prevailing wind direction and salinity. Twelve events, which lasted from 2 to 9 days, were evaluated for site WN2; daily maximum salinity ranges for these events differed by as little as $2.1 \mathrm{ppt}$ to as much as

B. Decreased salinity
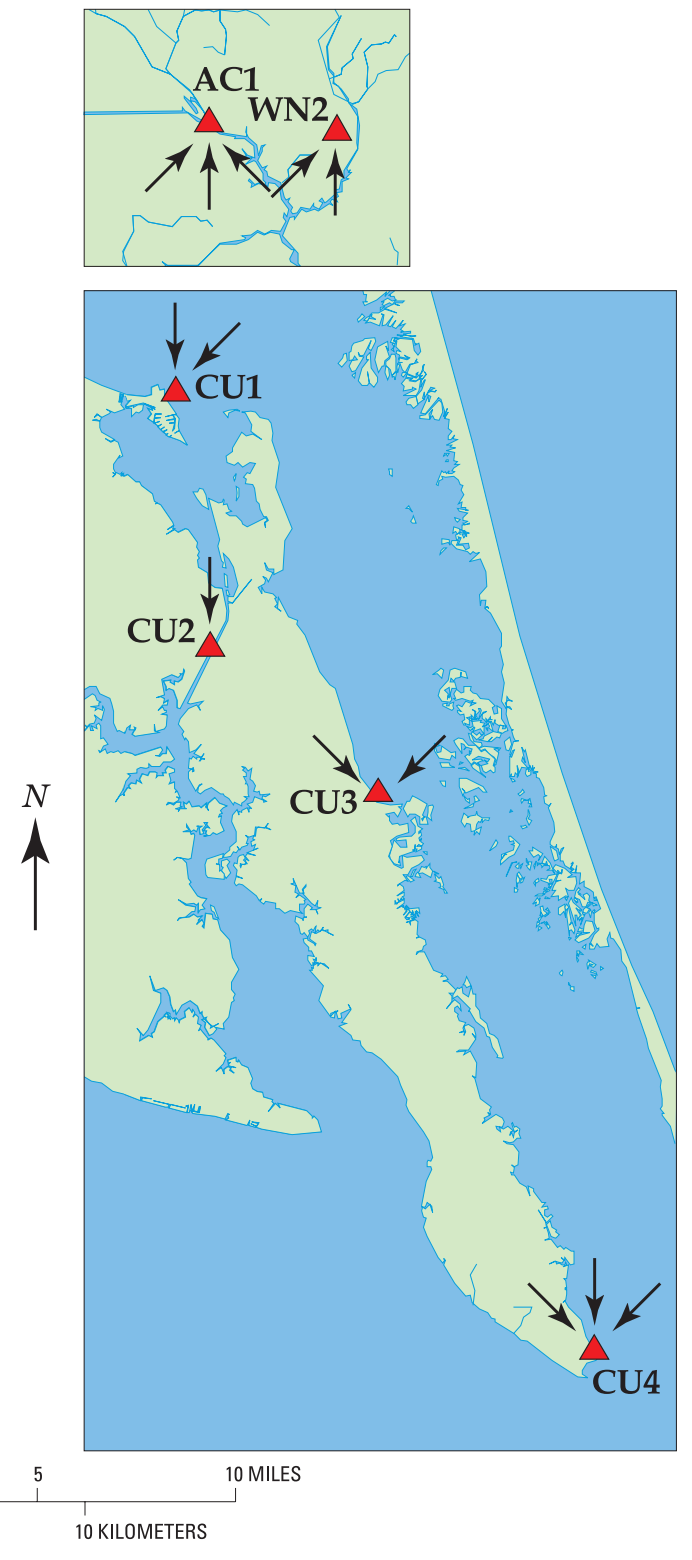

U4

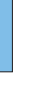




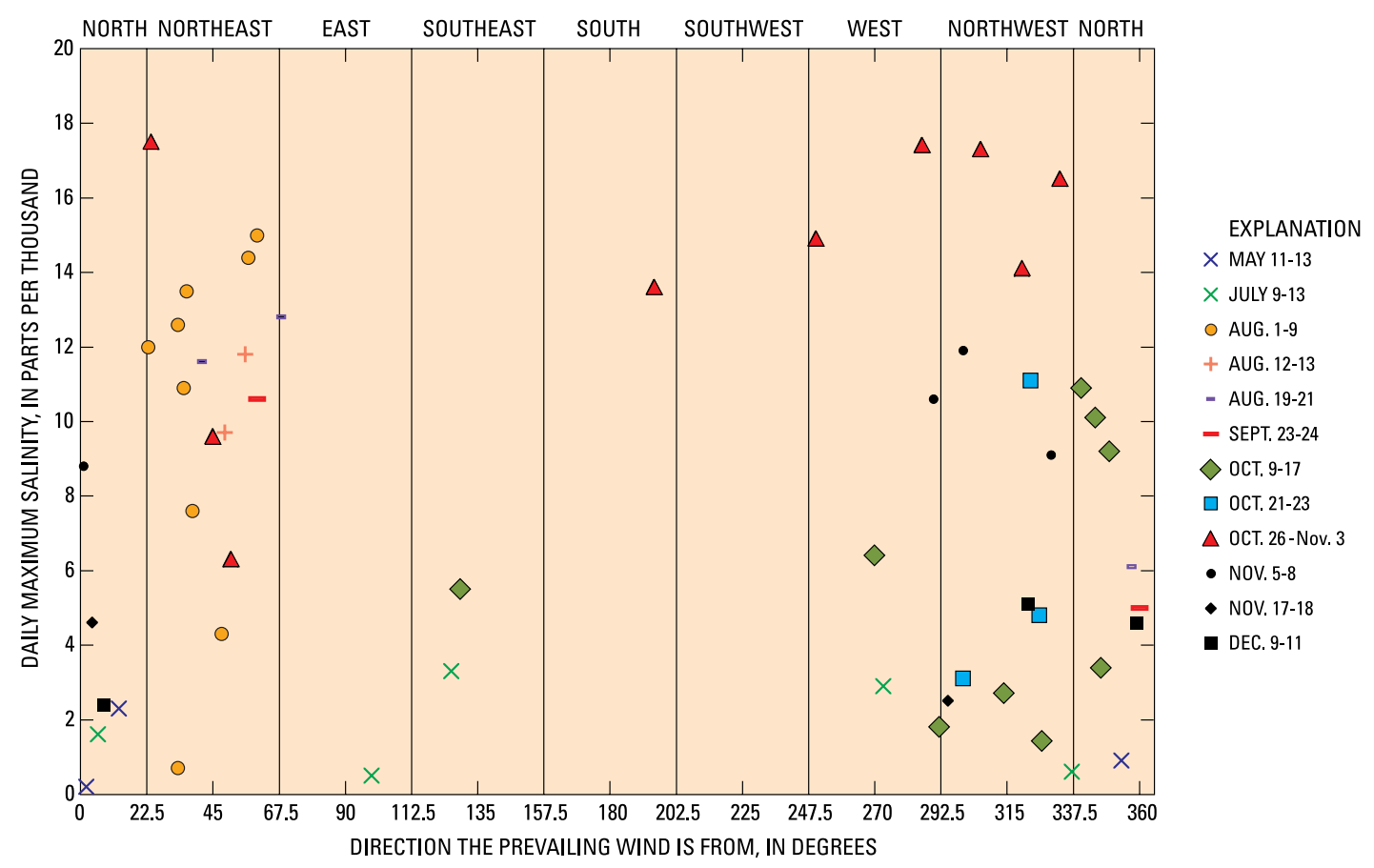

Figure 14. Relation of the direction of prevailing winds and daily maximum salinities at West Neck Creek (site WN2) during selected periods.

these events differed by as little as $0.7 \mathrm{ppt}$ to as much as $2.3 \mathrm{ppt}$ (fig. 15). Winds during these selected events were generally from the west or south, generating flows to the north.

The smallest salinity variations were observed at sites CU1 and CU3, where salinity remained less than 4 ppt throughout the study period (fig. 9). The highest salinities at site CU1 were associated with winds from the west and northwest. The highest salinities at site CU3 were associated with winds from the south and southwest (table 8).

Five events, which lasted from 2 to 6 days, were evaluated for site CU4; daily maximum salinity ranges for these events differed by as little as $1.2 \mathrm{ppt}$ to as much as $15.4 \mathrm{ppt}$ (fig. 16). Winds from the south and southwest tended to increase salinity at site CU4. During the period August 23-28, winds associated with
Hurricane Bonnie first blew from the south and southwest for 3 consecutive days, causing an increase in salinity; the winds then shifted from the east for the 3 remaining days of the period (fig. 16). During the last 3 days, winds from the east ranged between 12 and $27 \mathrm{mph}$. On August 28, salinity peaked and then began to decrease.

There was a statistically significant correlation between water level and salinity at all sites during the study period (fig. 17). This correlation was positive for sites CU3 and CU4 when salinities were greater than or equal to 2 ppt (fig. 17). Salinity increased at sites WN2, $\mathrm{AC} 1, \mathrm{CU} 1$, and CU2 as daily maximum water level decreased (correlations between -0.34 and -0.61). Conversely, salinity increased at sites CU3 and CU4 as daily maximum water level increased (correlations between 0.45 and 0.53 , respectively). 


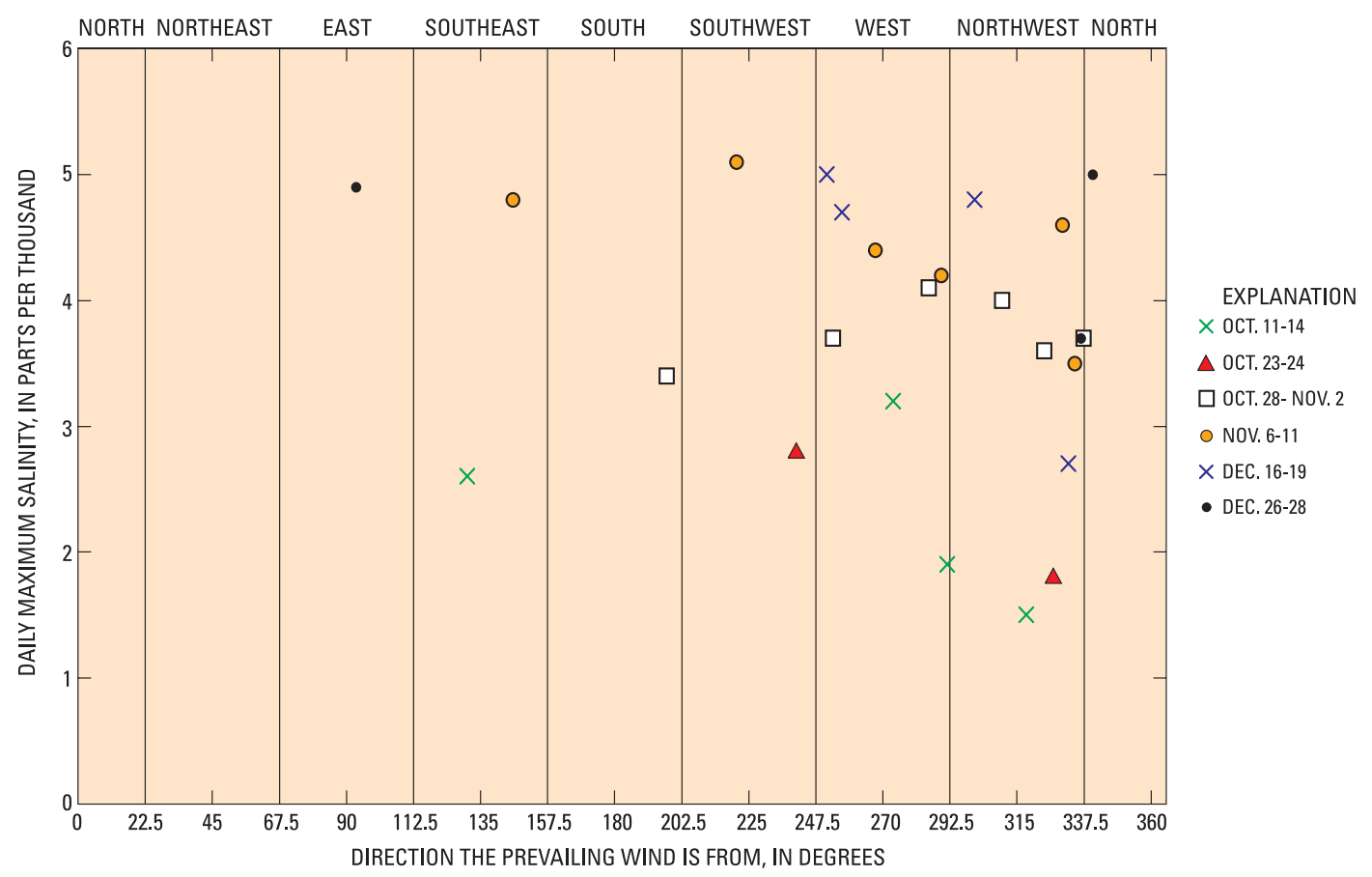

Figure 15. Relation of the direction of prevailing winds and daily maximum salinities at Coinjock (site CU2) during selected periods.

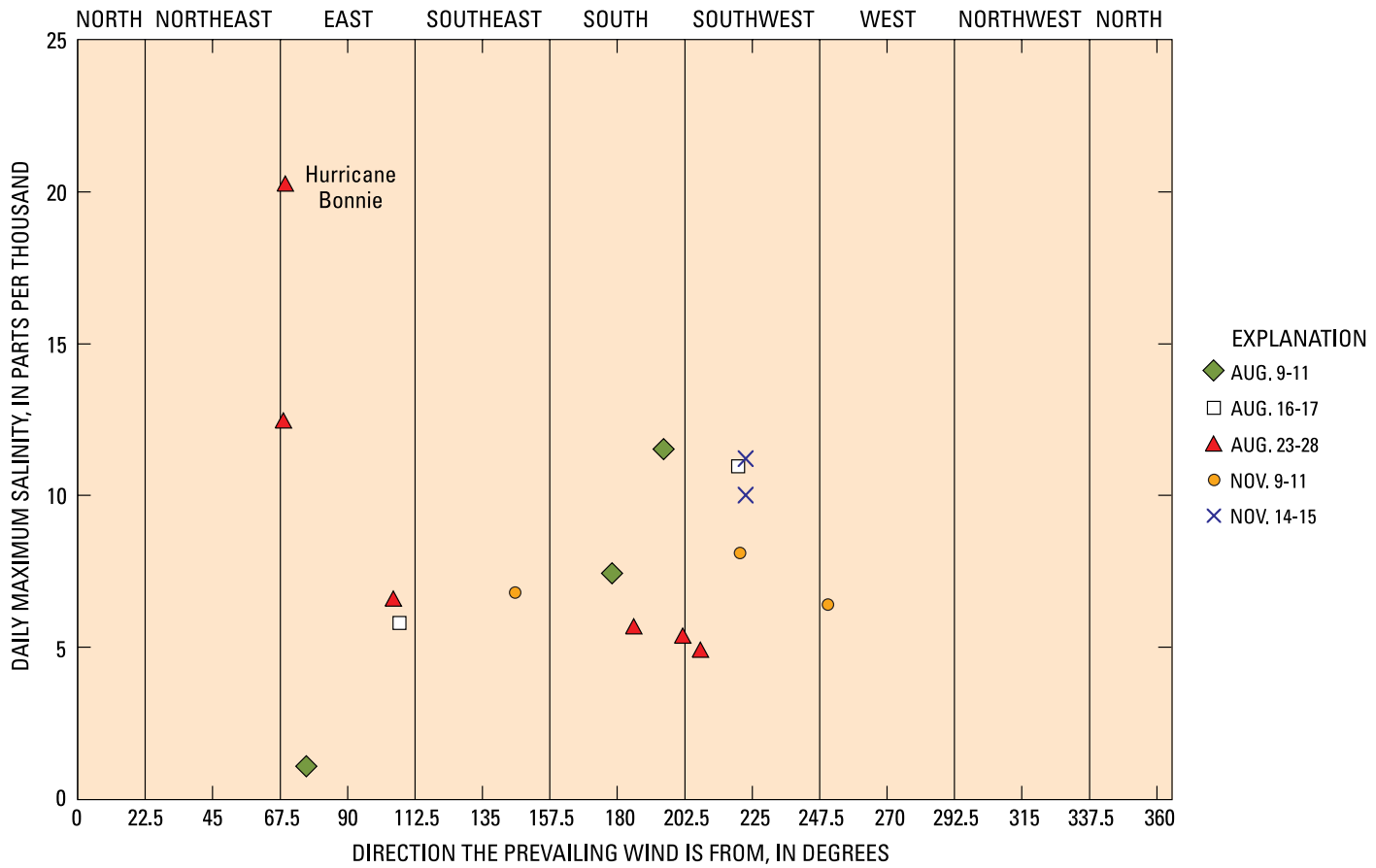

Figure 16. Relation of the direction of prevailing winds and daily maximum salinities at Point Harbor (site CU4) during selected periods. 

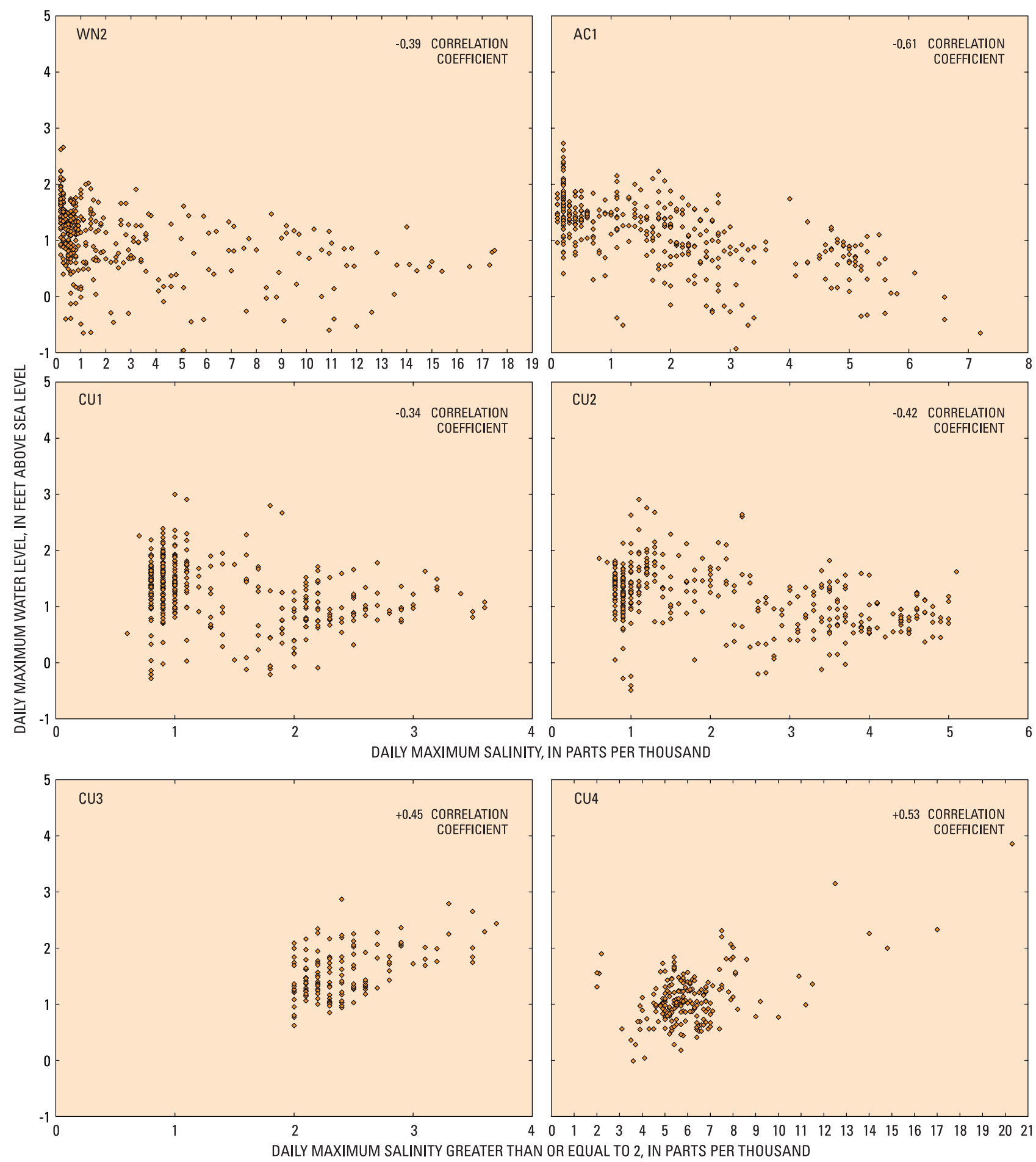

Figure 17. Comparison of daily maximum salinity and daily maximum water level at the Currituck Sound and tributary sites for the period March 1, 1998, to February 28, 1999. 


\section{Salt Loads}

Daily salt loads were computed for sites WN2 (fig. 18) and CU2 (fig. 19) by using salinity and flow data measured in 15-minute intervals. Data were available to compute loads for 364 days at site WN2 and 348 days at site CU2 from March 1, 1998, to February 28, 1999. As mentioned previously, days of missing record were assigned a null value that did not increase or decrease the cumulative salt load. The cumulative salt loads at sites $\mathrm{WN} 2$ and CU2 were 28,170 tons to the south and $-872,750$ tons to the north, respectively (figs. 18, 19).

If all of the salt load at WN2 were transported into Currituck Sound (volume of approximately 489,600 acre-ft in North Carolina) and uniformly distributed through the sound and no additional salt left the sound, salinity in the sound would be $0.01 \mathrm{ppt}$. If the total salt load at site CU2 were transported into the sound and uniformly distributed throughout the sound, salinity in the sound would be $0.32 \mathrm{ppt}$. The net transport at sites WN2 and CU2 indicates inflow of salt into the sound. In addition, the sound receives a constant inflow of freshwater from tributaries and ground-water sources; however, the net flow volumes from these freshwater sources are not documented, and the significance of these freshwater inflows toward diluting the net import of salt into the sound is beyond the scope of this study.

Bales and Skrobialowski (1994) computed cumulative salt loads at West Neck Creek at State Road 149 (approximately 3 mi north of site WN2) for 294 days during September 1990 through March 1992. The cumulative salt load at site WN2 for 364 days during the current study (fig. 18) was 18 percent less than the cumulative salt load observed by Bales and Skrobialowski (1994). The difference in cumulative salt load between these two sites could be due to natural year-to-year variation in salt loads.

For the majority of time at site WN2, salt transport was small. The mean daily salt load was 77 tons to the south, and the median daily transport was 30 tons to the south. The largest part of the salt load at this site occurred during four distinct events (May, August, October, and February; fig. 18). The maximum observed daily salt load to the south was 989 tons, which occurred on August 6, 1998. The maximum observed daily salt load to the north was -586 tons, which occurred on November 11, 1998, following the late October-early November transport of salt to the south (fig. 18; table 9).

At site CU2, the mean daily salt load was $-2,510$ tons to the north, and the median daily transport was $-1,530$ tons to the north. The largest part of the salt load at this site occurred during five distinct events (May, August, October, December, and February; fig. 19). The maximum observed daily salt load to the south was 55,257 tons, which occurred on November 12, 1998. The maximum observed daily salt load to the north was $-65,709$ tons, which occurred on January 3, 1999 (fig. 19; table 9).

The maximum daily salt load to the south at site WN2 was associated with daily average wind speeds of $12 \mathrm{mph}$ from the northeast and no accumulation of precipitation (table 9). Total daily flow was near average ( 98 percent of mean daily total flow to the south; table 3 ). The maximum daily salt load to the north at site WN2 was associated with daily average wind speeds of $15 \mathrm{mph}$ from the southwest and no accumulation of precipitation (table 9). Total daily flow was three times greater than average (308 percent of mean daily total flow to the north; table 3 ).

The maximum daily salt load to the south at site CU2 was associated with 10-mph winds from the north and no recorded precipitation at site WS2 (table 9). Total daily flow was more than double the average flow. The maximum daily salt load to the north at site CU2 was associated with 18-mph winds from the southwest and no recorded precipitation. Total daily flow was more than double the average flow (244 percent of mean daily total flow to the north; table 3).

Flow models would be useful in quantifying the salt loads from sites AC1 and CU4. As discussed previously, the salt source from site $\mathrm{AC} 1$ seems to be negligible as the salt is diluted while flow is moving south into North Landing River. Salt loads at site CU4 from the Albemarle Sound are not well defined. The increasing salinity trend within the sound may not be due to an increased input of salt but rather to a decrease in freshwater input as a result of channelization and rerouting of surface runoff inflows into the sound. Further investigation would help to determine a trend in freshwater inputs into the sound. 

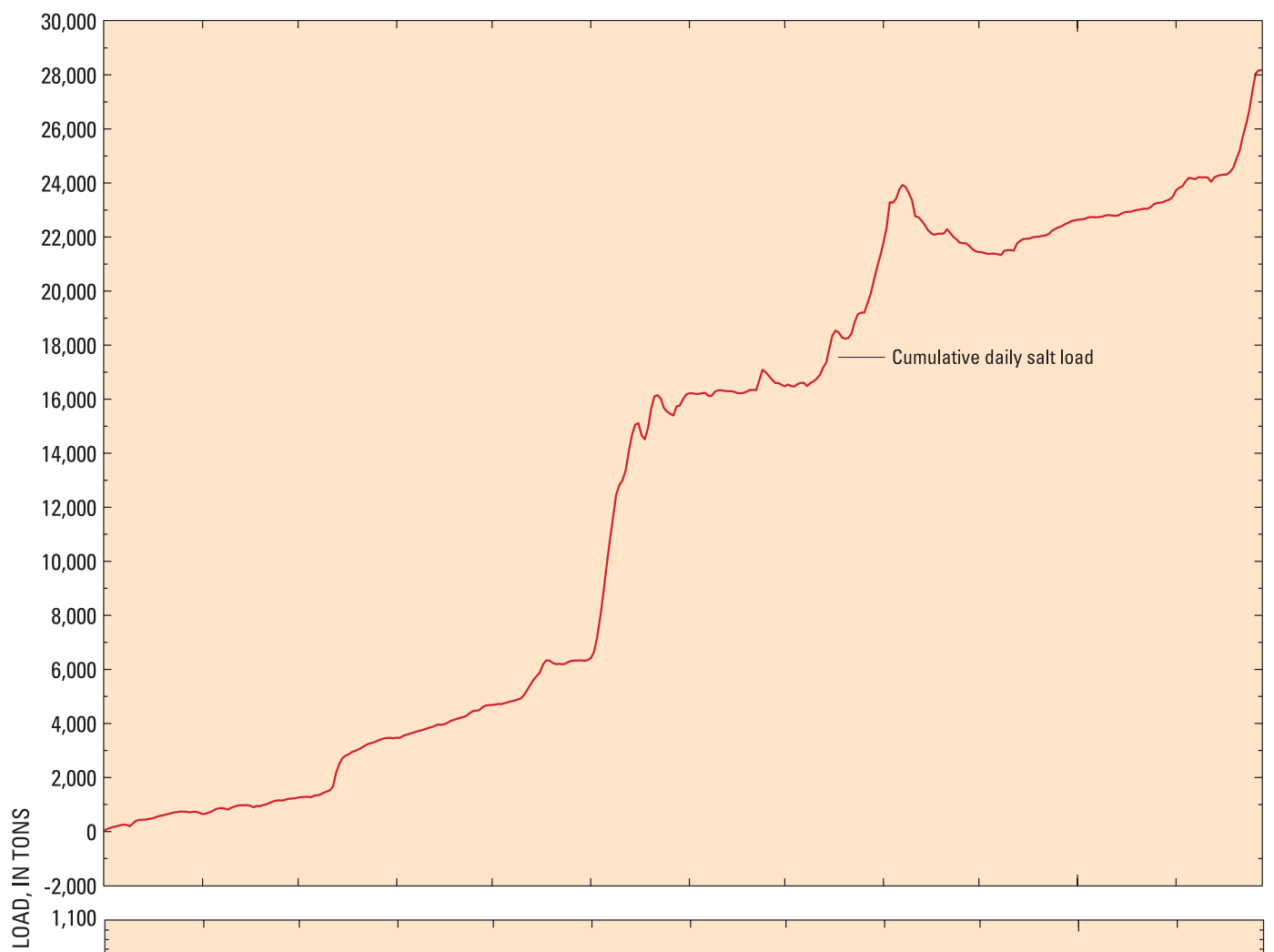

志 1 .

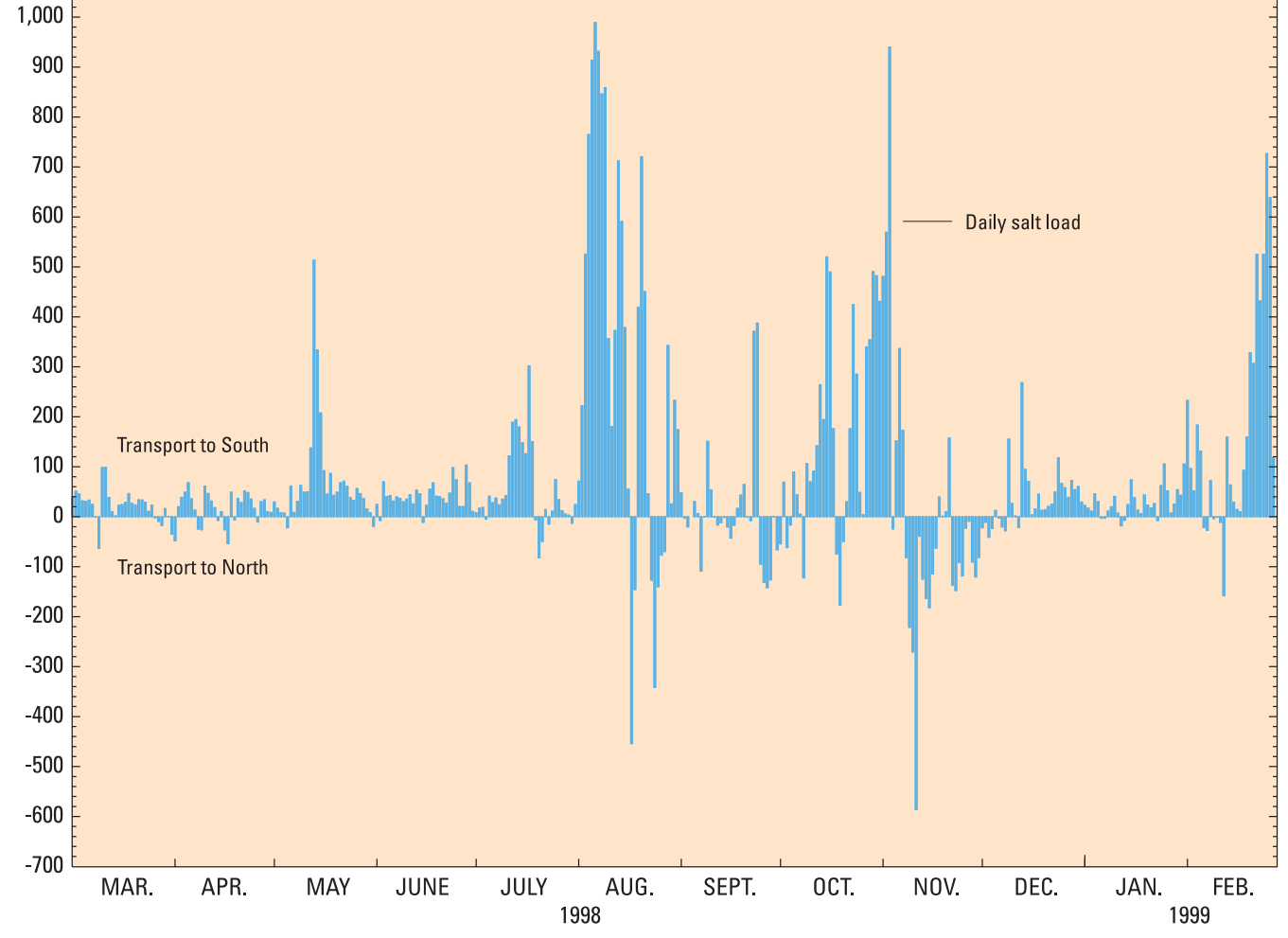

Figure 18. Daily and cumulative daily salt loads, in tons, at West Neck Creek (site WN2) for the period March 1998 through February 1999. 


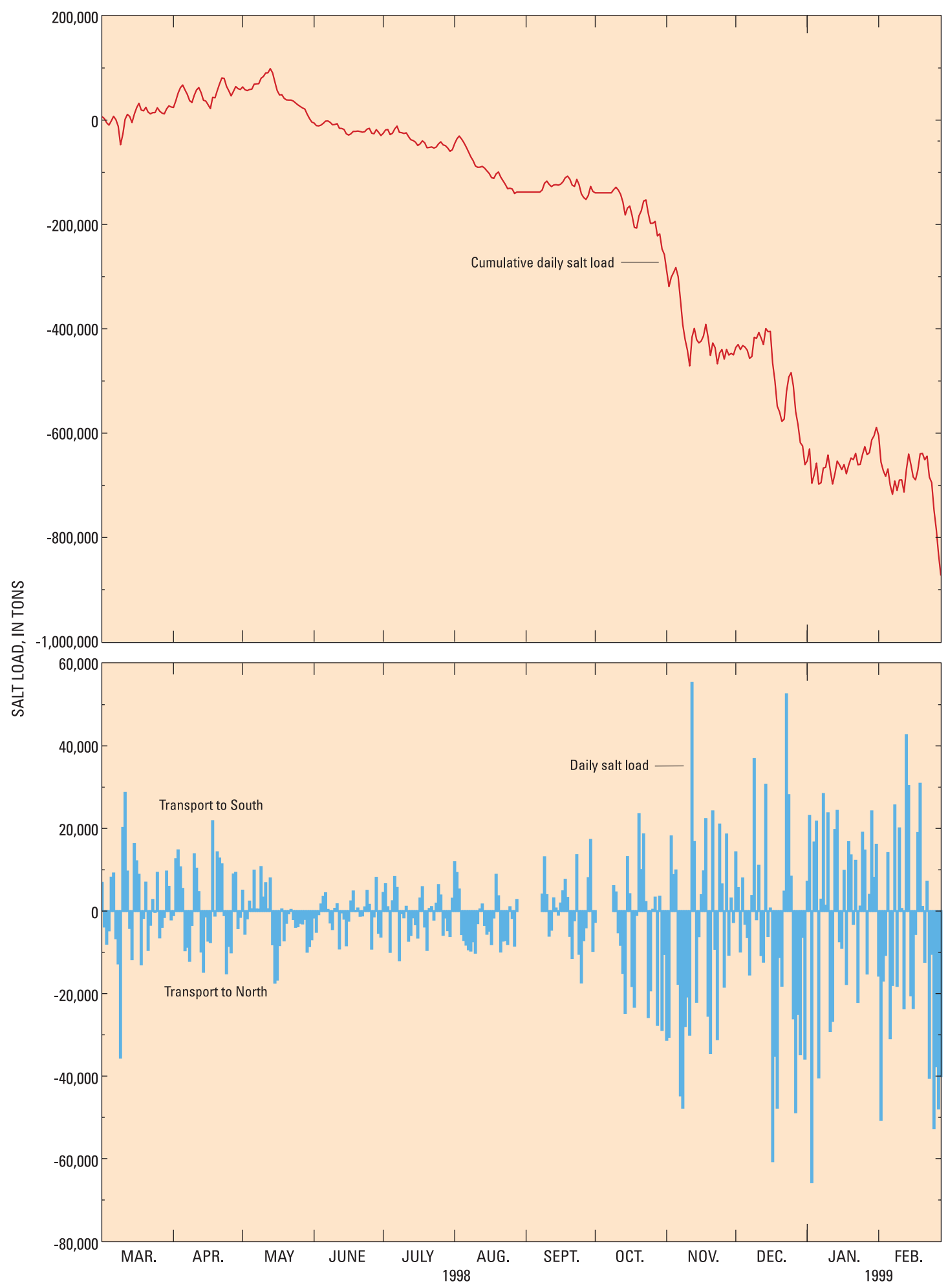

Figure 19. Daily and cumulative daily salt loads, in tons, at Coinjock (site CU2) for the period March 1998 through February 1999. 
Table 9. Summary of the highest daily salt loads at West Neck Creek (site WN2) and Coinjock (site CU2) and the relation of precipitation, flow, and wind direction and speed

[ $\mathrm{ft}^{3}$, cubic feet; $\mathrm{mph}$, miles per hour; - , no data. Positive values are to the south; negative (-) values are to the north]

\begin{tabular}{|c|c|c|c|c|c|c|c|}
\hline \multirow{2}{*}{$\begin{array}{l}\text { Site } \\
\text { (fig. 1) }\end{array}$} & \multirow{2}{*}{ Date } & \multirow{2}{*}{$\begin{array}{c}\text { Daily } \\
\text { salt } \\
\text { load } \\
\text { (tons) }\end{array}$} & \multicolumn{2}{|c|}{$\begin{array}{l}\text { 24-hour precipitation } \\
\text { (inches) }\end{array}$} & \multirow{2}{*}{$\begin{array}{c}\text { Daily } \\
\text { net } \\
\text { flow } \\
\text { volume } \\
\left(\mathrm{ft}^{3}\right)\end{array}$} & \multirow{2}{*}{$\begin{array}{l}\text { Prevailing } \\
\text { wind } \\
\text { direction } \\
\text { (from) }\end{array}$} & \multirow{2}{*}{$\begin{array}{c}\text { Daily } \\
\text { average } \\
\text { wind } \\
\text { speed } \\
\text { (mph) }\end{array}$} \\
\hline & & & WS1 & WS2 & & & \\
\hline \multirow{4}{*}{ WN2 } & $8-6-98$ & +989 & 0 & 0 & $+3.33 \times 10^{6}$ & Northeast & 12 \\
\hline & $8-17-98$ & -454 & .12 & .03 & $-2.10 \times 10^{6}$ & Southwest & 10 \\
\hline & $11-2-98$ & +940 & 0 & - & $+1.24 \times 10^{6}$ & North & 2 \\
\hline & $11-11-98$ & -586 & 0 & - & $-4.92 \times 10^{6}$ & Southwest & 15 \\
\hline \multirow{4}{*}{ CU2 } & $11-12-98$ & $+55,257$ & 0 & - & $+4.22 \times 10^{8}$ & North & 10 \\
\hline & $12-17-98$ & $-60,605$ & .2 & 0 & $-5.66 \times 10^{8}$ & West & 10 \\
\hline & $12-23-98$ & $+52,506$ & 0 & .5 & $+4.47 \times 10^{8}$ & North & 15 \\
\hline & 1-3-99 & $-65,709$ & 0 & - & $-5.45 \times 10^{8}$ & Southwest & 18 \\
\hline
\end{tabular}

\section{SUMMARY}

Currituck Sound is a brackish-water estuary that lies in the northeastern part of North Carolina in the Coastal Plain Physiographic Province. The sound has a surface area of about 97,900 acres, or about $153 \mathrm{mi}^{2}$, and has an average depth of about $5 \mathrm{ft}$. The sound extends $40 \mathrm{mi}$ southward from the Virginia-North Carolina State line to its confluence with the Albemarle Sound. The drainage basin, composed of tributaries from both North Carolina and Virginia, including Back Bay, is estimated to be $733 \mathrm{mi}^{2}$, of which almost onethird is open water. Most of the land that drains to Currituck Sound is located in the cities of Virginia Beach and Chesapeake, Virginia, and in northwest Currituck County, North Carolina.

During March 1, 1998, to February 28, 1999, data were collected at three sites in Currituck Sound and at three tributary sites. Data were used to characterize the hydrologic and salinity regime of Currituck Sound to better identify potential sources of salt to the sound. The Currituck Sound sites were located at Bell Island, Poplar Branch, and Point Harbor, and the tributary sites were on West Neck Creek at Pungo, the Albemarle and Chesapeake Canal near Princess Anne, and the Atlantic Intracoastal Waterway at Coinjock. The data collected included measurements of water level, velocity, flow, salinity, and temperature.

The maximum water-level range was observed near the lower midpoint of Currituck Sound at Poplar Branch (site CU3); the lowest water-level ranges were near the upper midpoint of the sound at Bell Island and Coinjock (sites CU1 and CU2, respectively). Water levels at all sites generally were higher during March and April and lower during November and December, and varied daily, seasonally, and annually.

Flow at West Neck Creek (site WN2) ranged from $313 \mathrm{ft}^{3} / \mathrm{s}$ to the south to $-227 \mathrm{ft}^{3} / \mathrm{s}$ to the north. Flow at Coinjock (site CU2) ranged from $15,300 \mathrm{ft}^{3} / \mathrm{s}$ to the south to $-11,700 \mathrm{ft}^{3} / \mathrm{s}$ to the north. Flow was to the south 68 percent of the time at site WN2 and 44 percent of the time at site CU2. During March 1, 1998, to February 28, 1999, the cumulative flow volume was $7.69 \times 10^{8} \mathrm{ft}^{3}$ to the south at site $\mathrm{WN} 2$ and $-1.33 \times 10^{10} \mathrm{ft}^{3}$ to the north at site CU2.

Precipitation alone had little effect on flow at sites WN2 and CU2, whereas wind direction and speed had a greater effect on flow at these sites. Flow at site WN2 was most likely to be to the north when winds were from the south to southwest, although winds from this direction do not always coincide with flows to the north because of fairly strong tidal effects at the site. At site CU2, flow was almost always to the south when winds were from the west-northwest to east-northeast.

On June 9, 1998, flow in Currituck Sound was measured at Point Harbor (site CU4). Two discharge measurements were made, and the average flow of the two measurements was $-19,500 \mathrm{ft}^{3} / \mathrm{s}$ to the northmore than eight times the flow to the north at site CU2 during the time of these measurements.

The mean and median salinities at each site were less than $3.5 \mathrm{ppt}$ for the study period except at site CU4; however, the maximum salinity exceeded $3.5 \mathrm{ppt}$ at all sites. Salinities were less than or equal to $3.5 \mathrm{ppt}$ at all sites more than 80 percent of the time, except at 
site CU4 where salinities were less than or equal to $3.5 \mathrm{ppt}$ less than 50 percent of the time. Salinities were less than or equal to $3.5 \mathrm{ppt}$ in Currituck Sound at Bell Island (site CU1) and Poplar Branch (site CU3) nearly 100 percent of the time, and in the Albemarle and Chesapeake Canal (site AC1) about 86 percent of the time. Salinities at sites CU2 and WN2 were less than or equal to $3.5 \mathrm{ppt}$ about 82 percent of the time. Daily maximum salinities throughout the study area differed by as much as $19.3 \mathrm{ppt}$ to as little as $0.8 \mathrm{ppt}$ during the study period.

Daily maximum salinities in the sound generally were lower from March to July 1998 but increased from August 1998 to February 1999. At sites CU1, CU2, and CU3, salinities were low from spring through mid-summer (April-July) and higher during the remainder of the study period (including March 1998). At sites WN2, AC1, and CU4, salinities were low from late winter through mid-summer (March-July) and generally higher from August 1998 through February 1999. More long-term data would be needed to determine if the slow increase in salinity in the sound following Hurricane Bonnie, which made landfall along the North Carolina coast during the early morning hours of August 27, 1998, was a typical seasonal response or a direct result of the storm.

Little association exists between flow volume and salinity at sites WN2 and CU2. Days when highest flows occurred did not coincide with days when highest salinities were observed. Prevailing northerly winds were associated with increased salinity at sites WN2 and $\mathrm{AC} 1$. At site WN2, daily net flows were to the south during the days with the highest salinities. At site CU2, prevailing winds from the south and southwest were associated with the highest salinities, and daily net flows were to the north.

Winds from the north generated flow to the south and, therefore, tended to increase salinities at sites WN2 and AC1. This indicates a salt source from Chesapeake Bay for site WN2 and from Great Bridge Lock for site AC1. Conversely, these same winds tended to lower salinities at sites CU1, CU2, CU3, and CU4. Prevailing winds from the south and southwest were associated with flow to the north and, therefore, tended to increase salinities at sites CU2, CU3, and CU4. This indicates a salt source from the Albemarle Sound. Southerly winds tended to lower salinities at sites WN2 and AC1.

The cumulative salt loads at sites WN2 and CU2 for the study period were 28,170 tons to the south and
$-872,750$ tons to the north, respectively. If all of the salt passing site WN2 were transported to Currituck Sound (approximately 489,600 acre-feet in North Carolina) and uniformly distributed throughout the sound, the salinity in the sound would be $0.01 \mathrm{ppt}$. Similarly, if the cumulative salt load at site CU2 were uniformly distributed throughout the sound, the salinity in the sound would be $0.32 \mathrm{ppt}$. The net transport at sites $\mathrm{WN} 2$ and CU2 indicates inflow of salt into the sound. There also is a constant inflow of freshwater from tributaries and ground-water sources; however, the net flow volumes from these freshwater sources are not documented, and the significance of these freshwater inflows in diluting the net import of salt into the sound is beyond the scope of this study.

\section{REFERENCES}

Bales, J.D., and Skrobialowski, S.C., 1994, Flow and salinity in West Neck Creek, Virginia, 1989-92, and salinity in North Landing River, North Carolina, 1991-92: U.S. Geological Survey Water-Resources Investigations Report 94-4067, 36 p.

Campbell Scientific, Inc., 1996, 247 conductivity/ temperature probe instruction manual, revision 3/96: Logan, Utah, copyright 1994-96, 11 p.

Eagleson, Kenneth, 1994, Currituck Sound outstanding resource waters evaluation: North Carolina Department of Environment, Health, and Natural Resources, Division of Environmental Management, Water Quality Section, $33 \mathrm{p}$.

Garrett, R.G., 1993, Water-quality data from continuously monitored sites in the Albemarle Sound estuarine system, North Carolina, 1989-91: U.S. Geological Survey Open-File Report 93-69, 257 p.

Garrett, R.G., and Bales, J.D., 1991, Water-quality data from continuously monitored sites in the Pamlico and Neuse River estuaries, North Carolina, 1989-90: U.S. Geological Survey Open-File Report 91-465, 151 p.

Hampton Roads Planning District Commission, 1992, Environmental management program for the southeastern Virginia portion of the Albemarle-Pamlico estuarine watershed: Raleigh, North Carolina Department of Environment, Health, and Natural Resources, Albemarle-Pamlico Estuarine Study, Report No. 92-543, 90 p.

International Organization for Standardization, 1985, International Standard 6416, Liquid flow measurement in open channels - measurement of discharge by ultrasonic (acoustic) method: Switzerland, International Organization for Standardization, $20 \mathrm{p}$. 
Kornegay, J.W., 1989, Currituck Sound fish population survey: Raleigh, North Carolina Wildlife Commission, Division of Boating and Inland Fisheries, Coastal Fisheries Investigation, Federal Aid in Fish Restoration Project F-22-14, 13 p.

Krug, W.R., Gebert, W.A., Graczyk, D.J., Stevens, D.L., Rochelle, B.P., and Church, M.R., 1990, Map of mean annual runoff for the Northeastern, Southeastern, and Mid-Atlantic United States, water years 1951-80: U.S. Geological Survey Water-Resources Investigations Report 88-4094, 11 p.

Laenen, Antonius, 1985, Acoustic velocity meter systems: U.S. Geological Survey Techniques of Water Resources Investigations, book 3, chap. A17, 38 p.

Malcolm Pirnie Engineers, Inc., 1980, Conditions in the Lynnhaven Estuarine System, Virginia Beach, Virginia: Newport News, Va., Study Report for the Department of the Army, Norfolk District Corps of Engineers, Norfolk, Va.

Miller, R.L., Bradford, W.L., and Peters, N.E., 1988, Specific conductance - theoretical considerations and applications to analytical quality control: U.S. Geological Survey Water-Supply Paper 2311, 16 p.

National Oceanic and Atmospheric Administration, 1998, Climatological data annual summary, North Carolina, 1998: National Oceanic and Atmospheric Administration, v. 103, no. 13, ISSN 0145-0794, $23 \mathrm{p}$.

1999, Climatological data annual summary, North Carolina, 1999: National Oceanic and Atmospheric Administration, v. 104, no. 13, ISSN 0145-0794, $23 \mathrm{p}$.

Overton, M.F., and McAllister, T.L., 1993, Flow and transport modeling of the London Bridge Creek-West Neck Creek system: Raleigh, North Carolina Department of Environment, Health, and Natural Resources, Albemarle-Pamlico Estuarine Study, Report No. 93-06, 23 p.

Ragland, B.C., Walters, D.G., Cartano, G.D., and Taylor, J.E., 2000, Water resources data, North Carolina, water year 1999: U.S. Geological Survey Water-Data Report NC-99-1A, 558 p.

Rideout, R.R., 1990, A comprehensive management plan for the Currituck Sound drainage basin-background investigations: Raleigh, North Carolina Department of
Environment, Health, and Natural Resources, Albemarle-Pamlico Estuarine Study, Report No. 90-19, $106 \mathrm{p}$.

Robinson, J.B., Hazell, W.F., and Garrett, R.G., 1996, Precipitation, streamflow, and water-quality data from selected sites in the city of Charlotte and Mecklenburg County, North Carolina, 1993-95: U.S. Geological Survey Open-File Report 96-150, 136 p.

Seaber, P.R., Kapinos, F.P., and Knapp, G.L., 1987, Hydrologic unit maps: U.S. Geological Survey WaterSupply Paper 2294, 63 p.

Tebo, L.B., and McCoy, E.G., 1964, Effects of sea-water concentration on the reproduction and survival of largemouth bass and bluegills: The Progressive Fish Culturist, v. 26, p. 99-106.

Thomas, C.D., 1996, Evaluation of supplemental largemouth bass stocking in three embayments of Currituck Sound, North Carolina, project F-22:

Raleigh, North Carolina Wildlife Resources Commission, final draft of project narrative, $9 \mathrm{p}$. 1998, Site specific effects of stocked largemouth bass fingerlings to year-class-strength at age-zero in Currituck Sound, North Carolina, project F-22: Raleigh, North Carolina Wildlife Resources Commission, final report, $25 \mathrm{p}$.

Trewartha, G.T., and Horn, L.H., 1980, An introduction to climate: New York, McGraw-Hill Publishing Co., $416 \mathrm{p}$.

U.S. Army Corps of Engineers, 1980, Virginia Beach streams, Canal Number Two general design memorandum phase 1, Virginia Beach, Virginia: Norfolk, Va., Norfolk District, 75 p. 1996, Section 1135 Preliminary Restoration Plan: Norfolk, Va., Norfolk District, 13 p., 3 pls.

U.S. Geological Survey, 1999, Strategic directions for the Water Resources Division, 1998-2008, 22 p.

Venters, Vic, 1995, Salt still plagues Currituck Sound largemouth populations: North Carolina Wildlife Resources Commission, Wildlife in North Carolina, v. 59, no. 6, p. 29.

Wilder, H.B., Robison, T.M., and Lindskov, K.L., 1978, Water resources of northeast North Carolina: U.S. Geological Survey Water-Resources Investigations 77-81, 113 p. 